Review

\title{
Life-Style and Serum Lipids and Lipoproteins
}

\author{
Yoshiya Hata and Kumiko Nakajima
}

Department of Medicine and Gerontology, Kyorin University School of Medicine, Tokyo, Japan.

\begin{abstract}
In reviewing the trends and influences of life-style in this country on health and disease in the latter half of 20th century, we focused our attention on 4 major habits of smoking, drinking, exercise and diets, and collected data on the Japanese to conduct a meta-analysis of their relationship with serum lipids and lipoproteins, which are the metabolic risk factors most closely related to atherosclerosis. 1) The percentage of smokers was $54.0 \%$ in adult males and $14.5 \%$ in adult females in 1999 . In the data of 7,256 subjects (mean age 47 years) in 16 papers, smoking increased triglycerides by $13 \mathrm{mg} / \mathrm{dl}(0.15 \mathrm{mmol} / \mathrm{L})$ or in 559 non-drinkers with a mean age of 49 years in 3 papers by $18 \mathrm{mg} / \mathrm{dl}(0.20 \mathrm{mmol} / \mathrm{L})$, and decreased HDL-cholesterol by $3.5 \mathrm{mg} / \mathrm{dl}(0.09 \mathrm{mmol} / \mathrm{L})$ with every 20 cigarettes smoked according to the regression equation. 2) As for drinking, the annual ethanol consumption per adult was $8.5 \mathrm{~L}$ in 1996 . The effects of alcohol on serum lipids were analyzed in 27,035 males (mean age 47 years) in 24 studies. Drinking elevated triglycerides by a mean of 10 $\mathrm{mg} / \mathrm{dl}(0.11 \mathrm{mmol} / \mathrm{L})$, and also $\mathrm{HDL}$-cholesterol by $2.5 \mathrm{mg} / \mathrm{dl}(0.06 \mathrm{mmol} / \mathrm{L}) \mathrm{per} 23 \mathrm{~g}$ of alcohol intake (corresponding to $1 \mathrm{go}$ of sake or 1 large bottle of beer). 3) Concerning exercise habit, $25 \%$ of males and $21 \%$ of females (mean age 47 years) regularly performed exercise such as jogging, swimming, aerobics, and tennis. However, walking was regarded as an easy exercise to be practiced by subjects of all ages. The effects of walking on serum lipids were studied in a total of 46,074 subjects (mean age 47 years) in 8 populations. Triglycerides were significantly lower by $10 \mathrm{mg} / \mathrm{dl}(0.11 \mathrm{~mol} / \mathrm{L})$, and $\mathrm{HDL}$-cholesterol higher by $3 \mathrm{mg} / \mathrm{dl}(0.08 \mathrm{mmol} / \mathrm{L})$ in those who walked 6,000 or more steps/day than in those who walked less than 2,000 steps/day. The effects of harder exercise like jogging or swimming were analyzed in 2,242 subjects in 14 papers (mean age 44 years). Triglycerides decreased by $10 \mathrm{mg} / \mathrm{dl}(0.11 \mathrm{mmol} / \mathrm{L})$, and $\mathrm{HDL}$-cholesterol elevated by $5 \mathrm{mg} / \mathrm{dl}(0.13 \mathrm{mmol} / \mathrm{L})$ with an increase in the exercise intensity by one level of about $300 \mathrm{kcal}$. In exercise therapy, triglycerides were decreased by a mean of $20 \mathrm{mg} / \mathrm{dl}(0.23 \mathrm{mmol} / \mathrm{L})$, and $\mathrm{HDL}$ -cholesterol increased by a mean of $10 \mathrm{mg} / \mathrm{dl}(0.26 \mathrm{mmol} / \mathrm{L})$ by exercise at a mean heart rate of about $135 \mathrm{bpm}$, which is equivalent to $50 \% \mathrm{VO}_{2 \max }$ for 30 minutes $\times 3$ times/week. 4) In nutritional trends, the mean energy intake in 52 postwar years averaged 2,116 \pm 84 kcal with no marked changes according to nutritional surveys. However, the percentage of fat in total energy intake was lowest at $7 \%$ in 1946, increased thereafter until it exceeded $20 \%$ in 1973 , and surpassed $25 \%$ in 1988 . The mean total cholesterol level of the Japanese increased by $28 \mathrm{mg} / \mathrm{dl}(0.72 \mathrm{mmol} / \mathrm{L})$ in the past 30 years and reached $204 \mathrm{mg} / \mathrm{dl}(5.28$ $\mathrm{mmol} / \mathrm{L}$ ) in a survey in 1990 . 5) Concerning dietary habits, total cholesterol was lower by a mean of $13 \mathrm{mg} / \mathrm{dl}(0.34 \mathrm{mmol} / \mathrm{L})$, triglycerides lower by $40 \mathrm{mg} / \mathrm{dl}(0.45 \mathrm{mmol} / \mathrm{L})$, and HDL-cholesterol higher by $5 \mathrm{mg} / \mathrm{dl}(0.13 \mathrm{mmol} / \mathrm{L})$ in the group who ate 7 or more Japanesestyle meals in the 9 meals during 3 days than in the group who ate 3 or less Japanese-style meals in the 9 meals. When serum lipids were compared among individuals living in cities ( 8 groups ; 3,613 subjects; mean age 51 years), agricultural villages (13 groups; 5,364 subjects ; mean age 51 years), and fishing villages ( 9 groups ; 1,071 subjects ; mean age 52
\end{abstract}

Address for correspondence: Yoshiya Hata, Department of

Medicine and Gerontololgy, Kyorin University School of

Medicine, 6-20-2, Shinkawa, Mitaka City, Tokyo 181-8611,

Japan.

Received December 27, 1999. 
years). Total cholesterol was lower by a mean of $10 \mathrm{mg} / \mathrm{dl}(0.26 \mathrm{mmol} / \mathrm{L})$ in fishing villages than in cities, and triglycerides lower by a mean of $15 \mathrm{mg} / \mathrm{dl}(0.17 \mathrm{mmol} / \mathrm{L})$ in fishing villages than in cities and agricultural villages. $\mathrm{HDL}$-cholesterol was $5 \mathrm{mg} / \mathrm{dl}(0.13 \mathrm{mmol} / \mathrm{L})$ higher in agricultural villages and $3 \mathrm{mg} / \mathrm{dl}(0.08 \mathrm{mmol} / \mathrm{L})$ higher in fishing villages than in cities. 6) The effects of dietary therapy or guidance were evaluated in 585 subjects (mean age, 53 years) in 12 papers. Total cholesterol was reduced by $20 \mathrm{mg} / \mathrm{dl}(0.52 \mathrm{mmol} / \mathrm{L})$, triglycerides by a mean of $40 \mathrm{mg} / \mathrm{dl}(0.45 \mathrm{mmol} / \mathrm{L})$, and $\mathrm{HDL}$-cholesterol was increased by $5 \mathrm{mg} /$ dl $(0.13 \mathrm{mmol} / \mathrm{L})$ by restriction of fat intake or restriction of the intake of saturated fat and dietary cholesterol. The results of these meta-analyses are considered to indicate the extent to which abnormalities of serum lipids are caused by a distorted life-style and the extent to which they are improved by correction of the life-style and exercise or dietary therapy. Correction of the life-style as a non-drug therapy may clearly improve hyperlipidemias or hypo-HDL-cholesterolemia so that this approach should be aggressively employed as part of the prevention and treatment for hyperlipidemias. $J$ Atheroscler Thromb, $2000 ; 7: 177-197$.

Key words : Life-style related disease, Smoking, Drinking, Exercise, Diet, Hyperlipidemias and Atherosclerosis

\section{Introduction}

At the time when Japan was defeated in the World War II in 1945, many people were compelled to rebuild their living on the verge of starvation in cities and towns reduced to ruins. It, however, accomplished economic restoration in only 50 years that followed. Now, cities bristle with towering buildings, paved roads penetrate deep into even remote mountainous areas, and coastlines have been reclaimed into sites of industrial complexes. Recently, Japan has been counted as one of the major industrialized countries called G7 or G9. The standard of living has improved, and the life-style of the Japanese has changed as an unprecedented living environment with automobiles incorporated in routine living, houses without tatami-floored Japanese-style rooms, easy access to tobacco and alcoholic beverages from vending machines, and frequent eating out as the whole family at a "family restaurant" has emerged.

Smoking, drinking, exercise, and diet are aspects of our life-style that has been maintained over centuries, but they have changed greatly and now exert different effects on the health of the Japanese from those in the past (1). The disease structure has changed, and the ranks of causes of death have shifted (2).

These 50 postwar years happened to be the second half of the 20th century. Evaluation of what effects changes in the life-style that took place in this period have exerted and are exerting on our health is considered to provide basic information for the determination of the direction of medical service in the 21 st century and to make great contributions to administrative decision making. Here, we would like to direct particular attention to the fact that the living environment has increased the incidence of diseases based on atherosclerosis until they account for death of one-third of the Japanese population through such aspects of the life-style as smoking, drinking, exercise and dietary habits (2). This article reviews what effects alterations in the living environment and consequent changes in the life-style had and are having on the serum lipid levels, which are metabolic parameters most closely related to atherosclerosis $(3,4)$.

For the convenience of discussion, smoking habit, drinking habit, exercise habit, and dietary habit are evaluated in this order with regard to their present state, effects on serum lipids, molecular mechanism of the effect, and relationships with atherosclerosis.

\section{Subjects and Methods}

First, the frequencies of smoking and exercise, and the amount of drinking, the intake of diets and the contents of nutrition (if data of the intake amount are not available, total production or total consumption were used), their changes, and their effects on the serum lipid levels were studied.

More specifically, 1) the percentage of smokers and its annual changes, effects of smoking on serum lipids, molecular mechanism of tobacco smoke on serum lipids, and relationship with atherosclerosis, 2) changes in the alcohol consumption and number of heavy drinkers, effects and mechanism of alcohol drinking on serum lipids and atherogenesis, 3) frequencies of exercise types at different age levels, percentage and serum lipid levels of regular exercisers, and effects of exercise therapies on serum lipids, and relationship of physical activities with atherosclerosis, 4) relationship between the changes in the energy ratio of fat in the diet and changes in the serum lipid levels, trends in the rice, fish, and meat consumption rates and the production of wheat as a material of bread, relationship between the frequency of ingestion of Japanese and Western diets and serum lipid levels, 
differences in the serum lipid levels between people living in urban areas and those living in agricultural or fishing villages and between Japanese emigrants and the native Japanese, and effects of dietary therapies on serum lipids and prevention of atherosclerotic vascular disease were studied.

For these purposes, 1) data published by relevant organizations were collected, and annual changes in the above habits from immediately after the end of the war were evaluated as much as possible; 2) then, research papers on the effects of these health-related habits on the serum lipid levels of the Japanese were searched primarily in the Igaku Chuo Zasshi (1987-present) and MEDLINE (1966-present) using key words as references. From each reference material, data concerning the effects of these health-related habits on the serum levels of total cholesterol, LDL-cholesterol calculated by the Friedewald formula, triglycerides, and HDL-cholesterol were collected, and meta-analysis was performed concerning the relationship between these habits and serum lipid levels. 3) In case of some references, in which data were presented only as graphs and not as measured values, approximate values read from enlarged graphs were used for the analyses. 4) Data were also collected for relationship between these habits and the incidence or the mortality rate of coronary heart disease in Japan, and 5) statistical analyses were performed using the mean values with adjustment of the relative weight according to the sample size, $t$-test, and single correlation analysis. The level of significance was $5 \%$ on two-tailed tests.

\section{Smoking habit and serum lipids}

As shown in Fig. 1, the percentage of smokers is widely different between males and females in Japan. In 1965, $82.3 \%$ of Japanese males were smokers, though this rate decreased to $58.8 \%$ after 30 years in 1995 and to $54.0 \%$ lately. In females, the percentage of smokers remained around $15 \%$, showing no marked changes, but was $14.5 \%$ in 1999. In females in their 20's, the percentage of smokers increased from $6.6 \%$ in 1965 to $23.3 \%$ in 1995 . It decreased slightly of late but still exceeds $20 \%$ (23.6\%). The percentage of smokers with males and females combined in $33.6 \%$. The percentage of smokers in males has decreased but is still high, and among the highest with France and Russia in advanced industrialized countries $(2,4)$.

We could collect 16 research papers that evaluated the relationship between the number of cigarettes smoked per day and serum lipid levels. The total number of subjects in these studies combined was 7,256 with a mean age of 47 years (5-20). Fig. 2 shows the relationships of the number of cigarettes smoked with the fasting serum levels of total cholesterol, LDL-cholesterol, triglycerides and HDL-cholesterol. The triglyceride level increased, while the HDL-cholesterol level decreased with increasing number of cigarettes smoked, and these correlations were significant. The HDL-cholestesrol level has been reported to decrease with smoking both in Japan and abroad, and the results of this meta-analysis support this conclusion. The slope of the regression equation suggests that the $\mathrm{HDL}$-cholesterol level decreases by $3.5 \mathrm{mg} / \mathrm{dl}(0.09$ $\mathrm{mmol} / \mathrm{L}$ ) with every 20 cigarettes smoked.

The triglyceride level is estimated to increase by $13 \mathrm{mg} /$ dl $(0.15 \mathrm{mmol} / \mathrm{L})$ with every 20 cigarettes smoked/day from the regression equation obtained. However, smoking is often accompanied by drinking, and the effect of drinking cannot be excluded. Therefore, the subjects of the collected studies were divided into drinkers and nondrinkers, and the results of 3 studies of the effects of smoking on triglycerides in non-drinkers were analyzed

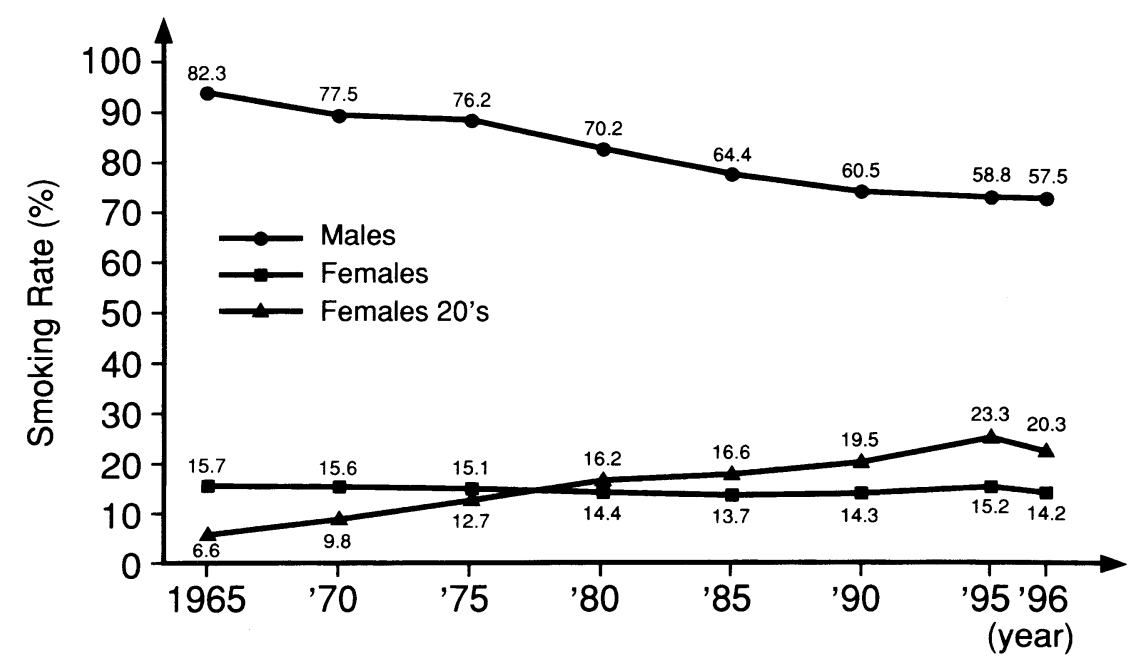

(Japan Tabacoo Industry : 1998)

Fig. 1. Trends in smoking rate in Japan. 

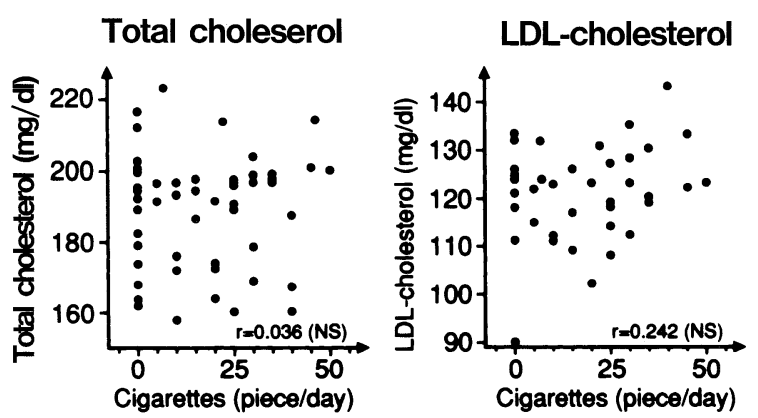

Triglycerides

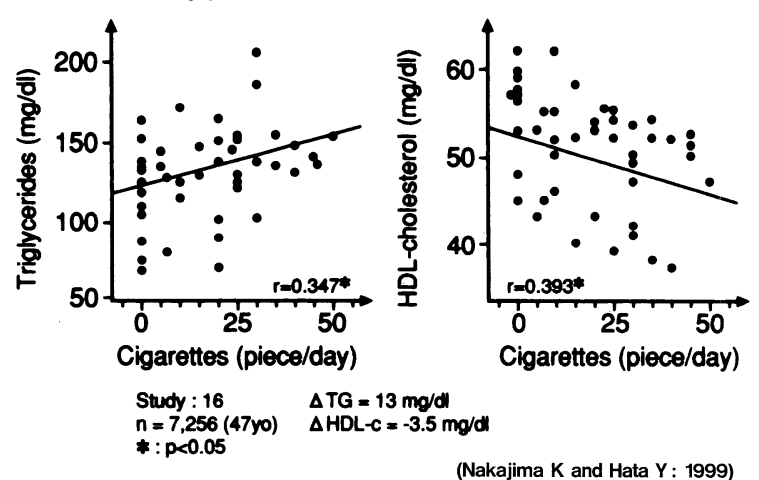

Fig. 2. Relationship between smoking habit and serum lipids and lipoproteins.

(559 subjects, mean age 49 years) $(8,11,16)$. As a result, the triglyceride level in non-smokers increased by a mean of $18 \mathrm{mg} / \mathrm{dl} \quad(0.20 \mathrm{mmol} / \mathrm{L})$ with every 20 cigarettes smoked. Therefore, smoking itself is considered to increase the triglyceride level by $13-18 \mathrm{mg} / \mathrm{dl}(0.15-0.20$ $\mathrm{mmol} / \mathrm{L})$ (about $15 \mathrm{mg} / \mathrm{dl}(0.17 \mathrm{mmol} / \mathrm{L}))$ per 20 cigarettes.

Concerning the mechanism of the decrease in the HDLcholesterol level associated with smoking, there have been reports that components of tobacco smoke are absorbed by the body and decrease the LCAT activity (21) and that components of tobacco smoke cause capillary spasms, decrease the peripheral blood flow, and thus decrease the contact between blood and capillary bed, with a consequent decrease in the lipoprotein lipase activity (21). The latter process may also explain the increase in the triglyceride level associated with smoking.

As for the lipoprotein-related mechanism of the progression of atherosclerosis due to smoking, modification or degeneration of LDL by tobacco smoke has been suggested to increase the uptake of degenerated LDL by macrophages $(22,23)$. Also, the ability of HDL to extract cholesterol from tissues is reported to be reduced when it is modified by tobacco smoke (24).

In regard to the relationship between smoking and atherosclerotic vascular disease, a positive linear relation was found as in Fig. 3. Relative risk of coronary heart disease doubled when one smoked 20 or more cigarettes a day (25). These findings were in line with the widely

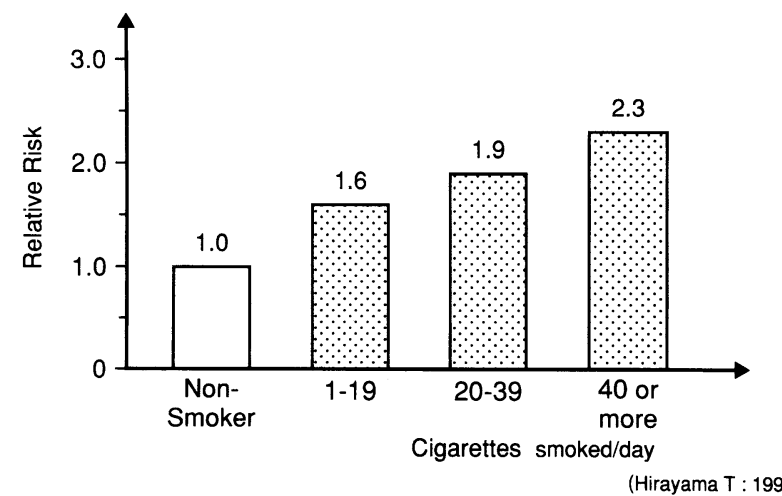

Fig. 3. Smoking habit and coronary heart disease in Japan.

known fact that the incidence of coronary and cereboveascular disease is significantly higher in smokers than in non-smokers (26-28).

\section{Drinking habit and serum lipids}

In Japan, the percentage of drinkers in 1996 was $52.2 \%$ in adult males and $9.4 \%$ in females $(2,4)$. There has been no investigation or report on the quantity of drinking in individuals. However, a section of "Alcohol" was incorporated in the chapter of "Health Promotion" in the 1987 edition of the Health Statistics of Japan, and the per capita alcohol consumption calculated by dividing the total consumption of pure ethanol (data of the National Tax Administration Agency) by the adult population was first shown (2). Fig. 4 shows changes in the annual per capita alcohol consumption calculated by this method from the year immediately after World War II. The annual per capita alcohol consumption, which was $2.34 \mathrm{~L}$ in 1951 , 6 years after the end of war, increased to a peak of about $9 \mathrm{~L}$ in 1992, which was the year before the collapse of the "bubble" of the Japanese economy, but decreased slightly

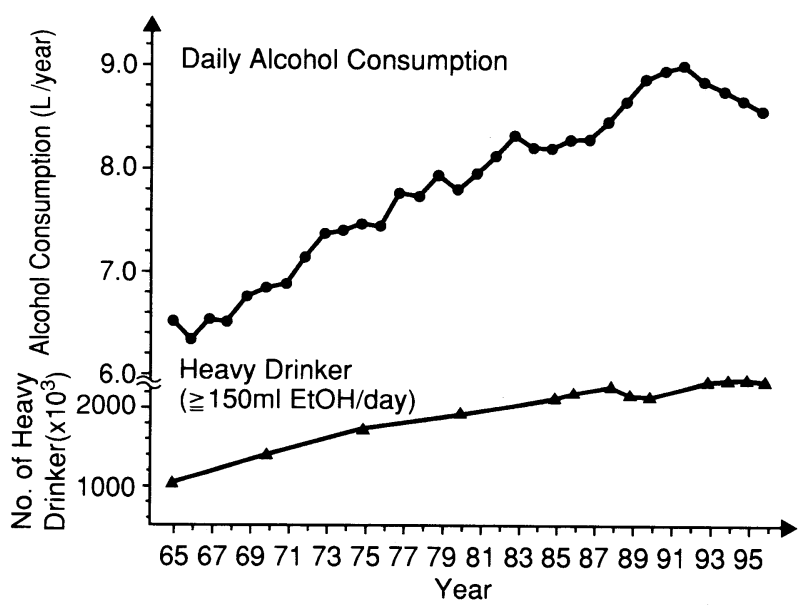

(Trends of Hygene of the Japanese : 2000)

Fig. 4. Trends in alcohol consumption and number of heavy drinkers in Japan. 
to $8.81 \mathrm{~L}$ in 1997. An annual alcohol consumption of $8 \mathrm{~L}$ corresponds to a large bottle of bear consumed by all Japanese adults daily. Fig. 4 (at the bottom) also shows the percentages of heavy drinkers who consumed $150 \mathrm{ml}$ or more ethanol per day. In and after 1992, the annual alcohol consumption has decreased slightly every year, but the percentage of heavy drinkers has not decreased; rather, it has tended to increase $(2,4)$.

We could find 24 research papers in which effcts of alcohol drinking on the serum lipid levels were studied $(6$, $7,9-13,15,16,18,19,29-41)$. The total number of subjects in these studies was 27,036 (mean age 47 years), and we performed a meta-analysis of the data of 26,712 males (mean age 47 years), excluding 324 females (mean age 35 years) in whom drinkers were few and the alcohol consumption was small. Fig. 5 shows the relationships between the alcohol intake and serum lipid levels in the males. The ethanol contents of various alcoholic beverages were calculated as in Table 1 on the basis of their reported ethanol concentrations.

No significant change associated with increases in the alcohol intake was observed in the total cholesterol or LDL-cholesterol level, but the triglyceride and HDL-cholesterol levels increased with the alcohol intake. From the slope of the regression equations, the serum triglyceride level was considered to increase by about $10 \mathrm{mg} / \mathrm{dl}$ $(0.11 \mathrm{mmol} / \mathrm{L})$, and the $\mathrm{HDL}$-cholesterol level to increase by $2.5 \mathrm{mg} / \mathrm{dl}(0.06 \mathrm{mmol} / \mathrm{L})$, with every additional $23 \mathrm{~g}$ of alcohol intake (1 go of sake or 1 large bottle of beer).

Concerning the mechanism of the increases in the serum triglyceride and HDL-cholesterol levels associated with alcohol intake, alcohol is considered to enhance the triglyceride synthesis in the liver (42) and secretion of VLDL from the liver (43). One cause of this enhancement of triglyceride synthesis and VLDL release is that alcohol promotes the release of free fatty acids from adipose tissues, which are taken up by the liver and used as substrates for triglyceride synthesis (44). Alcohol also
Total cholesterol

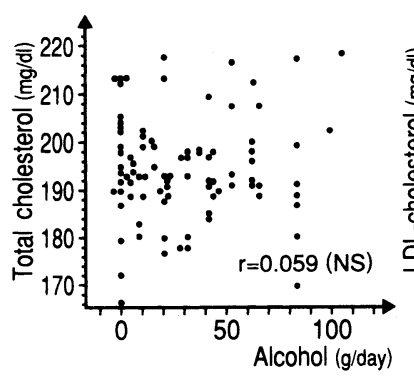

Triglycerides

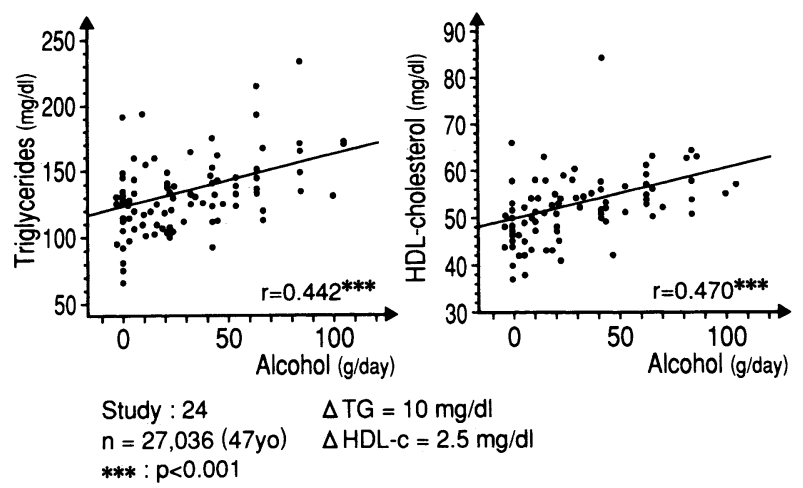

(Nakajima $K$ and Hata $Y: 1999)$

Fig. 5. Relationship between daily alcohol intake and serum lipids and lipoproteins.

increases the activity of lipoprotein lipase and enhances hydrolysis of VLDL-triglycerides (45) so that the circulating triglyceride concentration is equilibriated between synthesis and degradation.

Drinking causes an increase in the serum level of HDLcholesterol, the primary fraction of which is $\mathrm{HDL}_{3}$ (46). Since the HDL fraction measured in the study that showed prevention of the occurrence of coronary heart disease

Table 1. References of the tolerable alcohol intake in hyperlipidemic subjects (per day).

\begin{tabular}{lcccc}
\hline $\begin{array}{c}\text { Alcoholic } \\
\text { Beverage }\end{array}$ & $\begin{array}{c}\text { Alcohol } \\
\begin{array}{c}\text { Toncentration } \\
(\%)\end{array}\end{array}$ & $\begin{array}{c}\text { Volume } \\
\begin{array}{c}\text { Equivalent to } \\
\text { of Alcohol } \\
(\mathrm{ml})\end{array}\end{array}$ & $\begin{array}{c}\text { Reference } \\
\text { Quantity } \\
\text { (container) }\end{array}$ & $\begin{array}{c}\text { Reference } \\
\text { Quantity } \\
(\mathrm{ml})\end{array}$ \\
\hline Beer & 4.5 & 666 & 1 large bottle & 663 \\
Sake & 5 & 600 & 1 large bottle & 663 \\
Whisky & 16.5 & 182 & 1 go & 180 \\
& 43 & 70 & 1 double & 60 \\
Brandy & 43 & 70 & 2 singles & 60 \\
Wine & 14 & 214 & A full bottle shared among 3 & 60 \\
& & & Half a cup & 250 \\
Shochu & 35 & 85 & $2 / 3$ of a cup & 90 \\
Vodka & 25 & 120 & 1 shot glass & 120 \\
\hline
\end{tabular}


associated with an increased $\mathrm{HDL}$ level was $\mathrm{HDL}_{2}$ (47), whether the increase in $\mathrm{HDL}_{3}$ due to drinking has the same effect as the increase in $\mathrm{HDL}_{2}$ is somewhat questionable.

However, with regard to the relationship between the alcohol intake and atherosclerosis, the incidence of atherosclerotic vascular disease is known to be lower world-wide in a group that consumes a moderate amount of alcohol than in a group that consumes no alcohol (47). This relationship was shown, for example in Fig. 6, in the ethnic Japanese living in Hawaii (48) (the upper panel) and the native Japanese living in Osaka (49) (the lower panel), though the moderate amount of alcohol consumption corresponding to the bottom level of the J-curve was different from $30 \mathrm{~g} /$ day to $50 \mathrm{~g} /$ day in the two studies. The total mortality rate is also reported to reveal a pattern of $\mathrm{J}$-curve similar to that of coronary heart disease in Hawaii study (48).

These results are considered to be due to the "negative risk factor" (50) of HDL among serum lipids and lipoproteins, but whether $\mathrm{HDL}_{3}$ accounts for all the antiatherosclerotic effect or not must still be evaluated as mentioned above.

\section{Exercise habit and serum lipids}

As shown in Fig. 7, the mean percentage of regular exercisers during the past 10 years was $25 \%$ in the males,
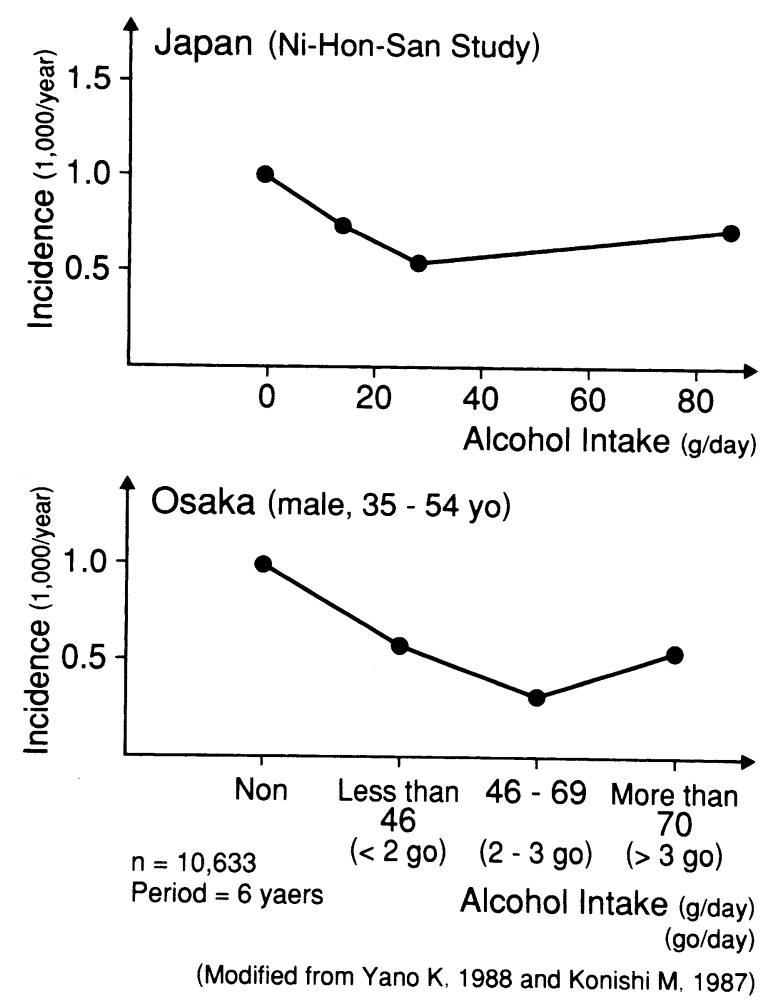

Fig. 6. Alcohol intake and coronary heart disease (cited from reference 48 with permission).

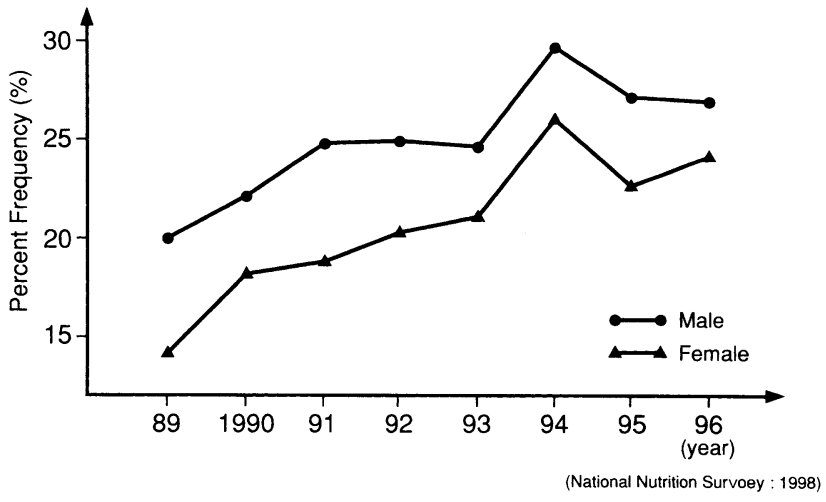

Fig. 7. The percentage of those who regularly exercise

$21 \%$ in the females, and about $23 \%$ in all subjects (mean age of the subjects, 47 years) (4). However, concerning the types of the exercise, those that require muscle activities of the whole body such as jogging, swimming, and tennis were mostly limited to young and middle-aged subjects, and walking was most often regarded as exercise in all generations including elderly individuals (1) as in Fig. 8. Therefore, walking should be included as a type of exercise in elderly individuals, who are likely to have impairments in motor and cardiorespiratory functions, and its relations with serum lipids and atherosclerotic disorders should be evaluated.

In evaluating the relationships between walking and serum lipids, data concerning the relationship between the daily number of steps of walking and serum lipids in 46,074 individuals (mean age 47 years) accumulated during the 8 years from 1989 to 1997 except 1990 presented in the Present Nutritional State of the Japanese (4) are informative. Figure 9 shows the mean serum lipid levels in individuals classified according to the daily number of steps of walking graded at intervals of 2,000 steps. The serum total cholesterol level showed no changes according to the daily number of steps, but the triglyceride level tended to decrease, and the HDL-cholesterol tended to

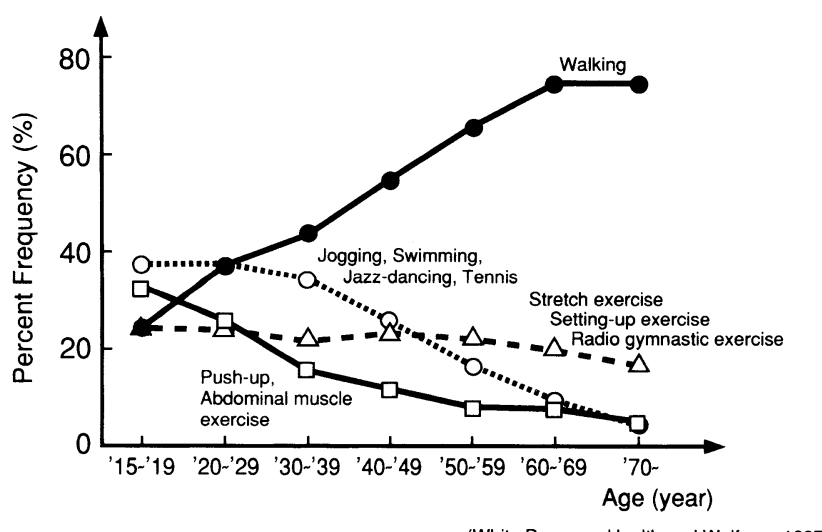

Fig. 8. Age and favored type of exercise. 


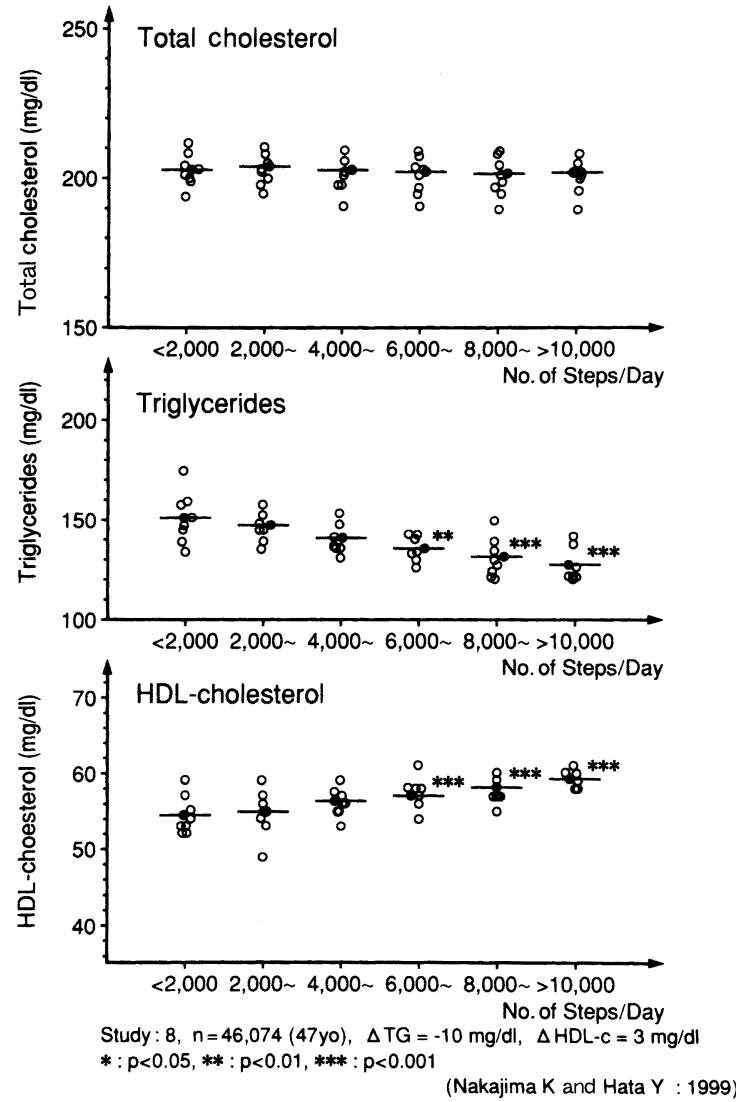

Fig. 9. The number of walking steps a day and serum lipids and lipoproteins.

increase, as the number of steps increased. The mean triglyceride and HDL-cholesterol levels showed significant differences in the groups that walked $>6,000$ steps/ day compared with the group that walked $<2,000$ steps/ day. The differences between the group that walked $>6,000$ steps/day and the group that walked $<2,000$ steps/day were $10 \mathrm{mg} / \mathrm{dl}(0.11 \mathrm{mmol} / \mathrm{L})$ in the triglyceride level and $3 \mathrm{mg} / \mathrm{dl}(0.08 \mathrm{mmol} / \mathrm{L})$ in the HDL-cholesterol. Walking is a fundamental physical activity, and walking $>6,000$ steps/day may significantly reduce the serum triglyceride level and significantly increase the serum HDL-cholesterol level. This must be kept in mind in instructing and treating hyperlipidemic subjects.

Next, Fig. 10 shows the results of 14 studies on the effects of exercise that require large muscle groups of the whole body in 2,523 individuals (2,242 males, 160 females, 121 of unknown sex) with a mean age of 44 years $(10,15$, 40,51-61). The exercise intensity was classified into 5 grades: Not doing exercise regularly (group 0 in Fig. 10), doing light exercise such as fast walking and light gymnastics 3 times or more per week (group 1 in Fig. 10), doing moderate exercise such as golf once a week, gate ball 12 times/week, and weight training 1-2 times/week (group 2 in Fig. 10), doing hard exercise such as jogging, swim-
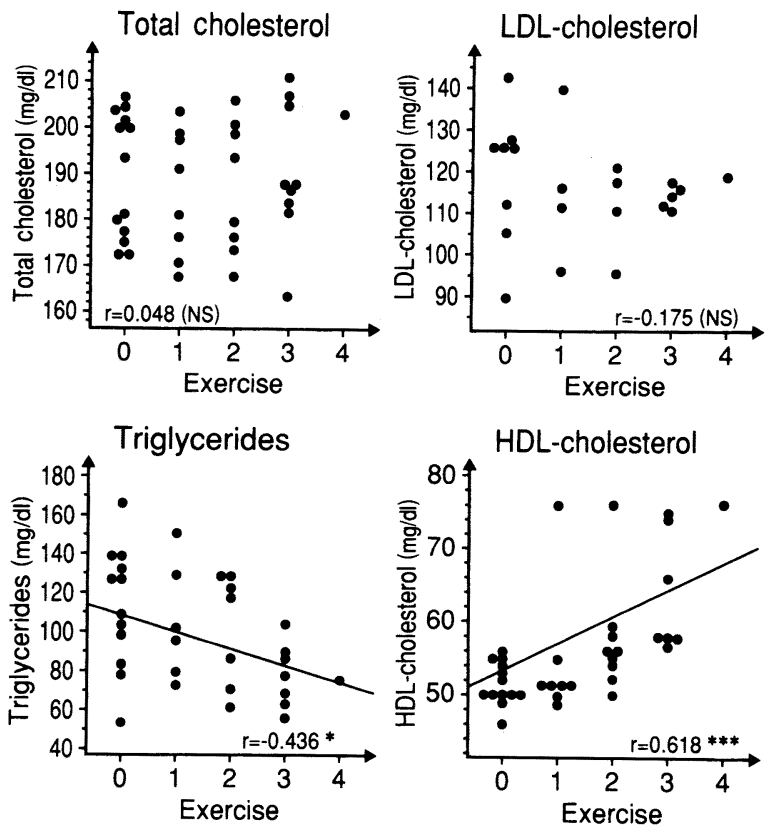

0 : No exercise, 1 : Light exercise, 2 : Moderate exercise,

3 : Intensive exercise, 4 : Endurance exercise

$\begin{array}{ll}\text { Study }: 14 & \Delta T G=-10 \mathrm{mg} / \mathrm{dl} \\ \mathrm{n}=2,242(44 \mathrm{yo}) & \Delta \mathrm{HDL}-\mathrm{c}=5 \mathrm{mg} / \mathrm{dl}\end{array}$

$n=2,242(44 y o)$
$*: p<0.05, * * *: p<0.001$

(Nakajima Kand Hata Y : 1999)

Fig. 10. Relationship between exercise habit and serum lipids and lipoproteins.

ming, jazz dancing, and tennis 30-60 minutes $\times 3$ or more times/week (group 3 in Fig. 10), and doing endurance exercise such as marathon (group 4 in Fig. 10). When the serum lipid levels were compared among these 5 groups, no significant difference was observed in the total cholesterol or LDL cholesterol level according to the exercise intensity, but significant differences were noted in the triglyceride and HDL-cholesterol levels; a significant negative correlation was observed in triglycerides, and a significant positive correlation was observed in HDLcholesterol. Thus, the earlier results that the triglyceride level decreases and the HDL-cholesterol level increases as one exercises harder was confirmed. From the data shown in Fig. 10, the triglyceride level decreased by 10 $\mathrm{mg} / \mathrm{dl}(0.11 \mathrm{mmol} / \mathrm{L})$, and $\mathrm{HDL}$-cholesterol level increased by $5 \mathrm{mg} / \mathrm{dl}(0.13 \mathrm{mmol} / \mathrm{L})$ as the exercise intensity was 1 grade higher.

Furthermore, Fig. 11 shows changes in the serum lipid levels associated with systematic performance of exercise therapies observed in 13 studies $(57,62-73)$. The total number of subjects was 728 (194 males and 519 females, sex not mentioned in 15) with a mean age of 48 years. Table 2 shows the exercise types employed in these studies. The treadmill or bicycle ergometer was used most frequently, followed by jogging, aerobic exercise, badminton, and fast walking. 

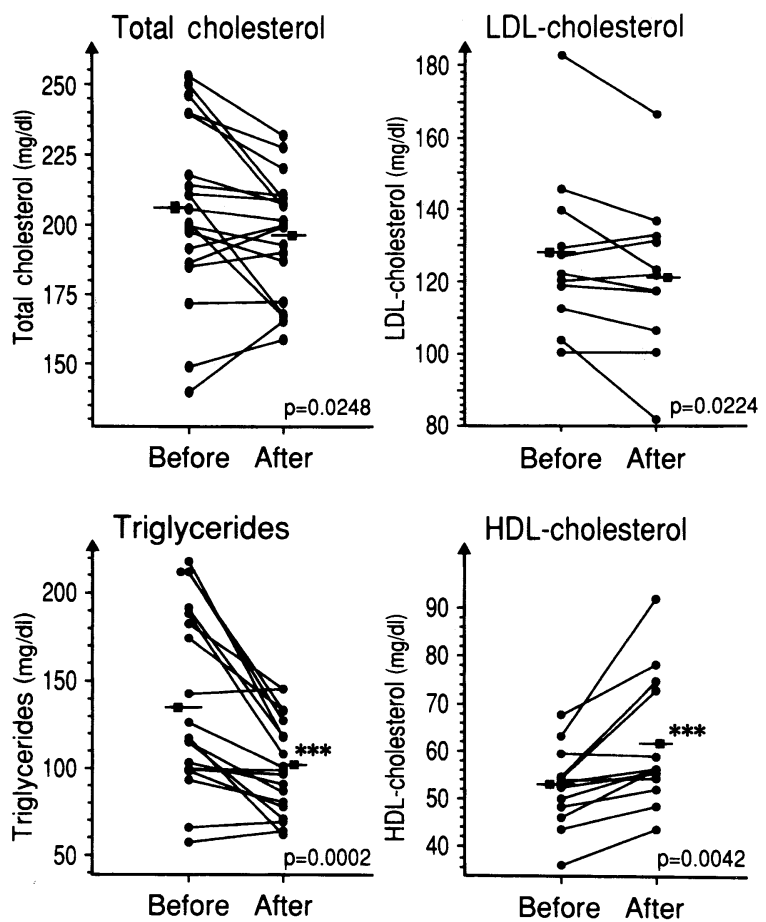

Study : 13, * : The mean of values before and after exercise $\mathrm{n}=728(\mathrm{~m}=194, \mathrm{f}=519),(48 \mathrm{yo}), \Delta \mathrm{TC}=-10 \mathrm{mg} / \mathrm{dl}, \Delta \mathrm{TG}=-20 \mathrm{mg} / \mathrm{dl}$ $* * *: p<0.001$ $\Delta \mathrm{HDL}-\mathrm{C}=10 \mathrm{mg} / \mathrm{dl}$

(Nakajima K and Hata $Y$ : 1999)

Fig. 11. Effects of exercise therapy on serum lipids and lipoproteins.
The intensity of exercise at $60-70 \%$ of the maximum oxygen uptake $\left(\mathrm{VO}_{2 \max }\right)$, a mean heart rate of $145 \mathrm{bpm}$, or an energy consumption of $500 \mathrm{kcal}$ was often regarded as strong, that of exercise at $50 \%$ of $\mathrm{VO}_{2 \max }$ or a mean heart rate of $135 \mathrm{bpm}$ as moderate, and that of exercise at about $30 \%$ of $\mathrm{VO}_{2 \max }$ and a mean heart rate of about $120 \mathrm{bpm}$ as mild. When fast walking was used for mild exereise load, fast walking of $7,500-10,000$ steps a day was required in some studies. In these studies the duration of one session was often 30 minutes, and the frequency of exercise was often 3 times/week. The mean duration of the studies was 16 weeks.

At the exercise intensity used for exercise therapy, the total cholesterol and LDL-cholesterol levels decreased in 7 of the 13 studies but increased in the remaining 6 studies, and no significant decrease was observed in all subjects combined. However, they decreased markedly when the exercise was hard enough to induce a reduction in the body weight. Therefore, exercise therapy that would cause a reduction in the body weight was also considered to be effective for reducing the total cholesterol level. The triglyceride level decreased, and the HDL-cholesterol level increased, significantly as in Fig. 11. After exercise therapies, the triglyceride level decreased by a mean of $20 \mathrm{mg} / \mathrm{dl}(0.23 \mathrm{mmol} / \mathrm{L})$, and the HDL-cholesterol level increased by a mean of $10 \mathrm{mg} / \mathrm{dl}(0.26$ $\mathrm{mmol} / \mathrm{L})$.

Fig. 12 shows the relationships of an index of the daily physical activity level representing all physical activities including exercise with coronary heart disease, cerebrovascular disease, and total mortality rate (74). The

Table 2. Types of exercise therapy and its intensity, frequency, and duration.

\begin{tabular}{|c|c|c|c|c|c|}
\hline Reporter & Exercise type & Intensity & $\begin{array}{l}\text { Duration } \\
\text { (min) }\end{array}$ & $\begin{array}{c}\text { Frequency } \\
\text { of a session } \\
\text { (times/week) }\end{array}$ & $\begin{array}{l}\text { Duration } \\
\text { (weeks) }\end{array}$ \\
\hline Higuchi M (1984) & Treadmill & $9 \mathrm{kcal} / \mathrm{kg}(=545 \mathrm{kcal})$ & & 5 & 4 \\
\hline Hashimoto I (1986) & Theadmill & $9 \mathrm{kcal} / \mathrm{kg}(=150 \mathrm{~m} / \mathrm{min}$ & & 3 & 4 \\
\hline Morino M (1987) & $\begin{array}{l}\text { Ergometer } \\
+7,000 \text { steps/day }\end{array}$ & $\begin{array}{l}\mathrm{O}_{2 \max } 50 \% \\
\mathrm{O}_{2 \max } 60 \% \\
\mathrm{O}_{2 \max } 70 \%\end{array}$ & $\begin{array}{l}30 \\
30 \\
30\end{array}$ & $\begin{array}{l}6 \\
6 \\
6\end{array}$ & $\begin{array}{l}5 \\
5 \\
5\end{array}$ \\
\hline Tanaka K (1988) & Jogging & $10 \mathrm{~km} /$ week & - & - & 12 \\
\hline Ohta T (1990) & Walking & 10,000 steps/day & - & - & 20 \\
\hline Kashihara H (1993) & $\begin{array}{l}\text { Walking }+ \\
\text { Aerobics seminor }\end{array}$ & 10,000 steps/day & - & every day & 12 \\
\hline Higuchi T (1993) & Bicycle Ergometer & $\begin{array}{l}\mathrm{O}_{2 \max } 30 \% \\
\mathrm{O}_{2 \max } 50 \%\end{array}$ & $\begin{array}{l}30 \\
30\end{array}$ & $\begin{array}{l}3 \\
3\end{array}$ & $\begin{array}{l}6 \\
6\end{array}$ \\
\hline Motoyama M (1994) & Treadmill & Lactate threshold & 30 & $3-6$ & 18 months \\
\hline Ishibashi K (1994) & $\begin{array}{l}\text { Walking } \\
\text { Running } \\
\text { Badminton }\end{array}$ & $\begin{array}{l}\text { HR } 120 \pm 17 \\
\operatorname{HR} 145 \pm 18 \\
\text { HR } 135 \pm 15\end{array}$ & $\begin{array}{l}30-60 \\
30-60 \\
30-60\end{array}$ & $\begin{array}{l}1-2 \\
1-2 \\
1-2\end{array}$ & $\begin{array}{l}10 \\
10 \\
10\end{array}$ \\
\hline Hirano K (1994) & $\begin{array}{l}\text { Walking } \\
\text { Treadmill or } \\
\text { Bicycle Ergometer }\end{array}$ & $\begin{array}{l}7,500 \text { steps/day } \\
\mathrm{O}_{2 \max } 60 \% \\
\mathrm{O}_{2 \max } 60 \%\end{array}$ & $\begin{array}{l}30-60 \\
30-60\end{array}$ & $\begin{array}{c}\text { every day } \\
3 \\
3\end{array}$ & $\begin{array}{l}6 \text { months } \\
<6 \text { months } \\
\geqq 6 \text { months }\end{array}$ \\
\hline Nakagawa N (1995) & Bicycle Ergometer & $\mathrm{O}_{2 \max } 50-60 \%$ & 30 & $5-6$ & 12 \\
\hline Higashi Y (1999) & Walking & Fast walking & 30 & $5-6$ & 12 \\
\hline
\end{tabular}




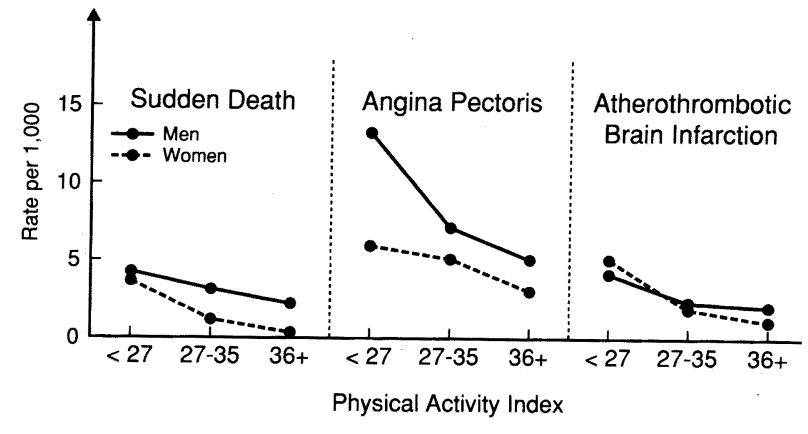

(Dawber TR : 1980)

Fig. 12. Relationship between physical activities and frequency of atherosclerotic vascular disease (cited from reference 74 with permission).

mortality rates due to coronary heart disease and cerebrovascular disorders were higher as the physical activity level was lower (74-76).

Exercise is considered to improve the lipoprotein metabolism by improving the insulin sensitivity, increasing hydrolysis of triglyceride-rich lipoproteins that contain high levels of triglycerides due to an enhancement of the lipoprotein lipase (LPL) activity, and inhibiting conversion of $\mathrm{HDL}_{2}$ to $\mathrm{HDL}_{3}$ due to a decrease in the hepatic lipase activity $(77,78)$. An enhancement of the lecithin-cholesterol acyltransferase activity and a decrease in the cholesteryl-estertransfer protein (CETP) are also considered to be involved in this mechanism (79-81).

Effects of exercise on atherosclerosis are considered to include not only betterment of the triglyceride level, which is a coronary risk factor, and the HDL-cholesterol level, but also reducing LDL-cholesterol when exercise is hard enough to decrease the body weight, improving the blood pressure and increasing the cardiorespiratory reserve (82, 83).

\section{Dietary habit and nutrition and serum lipid levels}

Effects of the diet on the serum lipid levels were evaluated with regard to the following three points: 1) Relationship between the current nutritional status of the Japanese and serum lipid levels, 2) relationships of the Japanese-style diet or a habit of eating fish and the serum lipid levels, and 3) effects of dietary guidance or dietary therapy on serum lipid levels.

\section{Nutritional trends and serum lipids}

First, the energy intake and the ratios of protein, fat, and carbohydrate in the total energy intake were presented in selected years (Fig. 13) (84). The energy intake in 1946, immediately after the World War II, was about $1,900 \mathrm{Kcal}$. In the subsequent years, the energy intake generally fell in a range of 2,000-2,200 kcal, and the mean energy intake during the 52 postwar years was $2,116 \pm 84 \mathrm{kcal}$. The percentage of fat in the total energy intake was only $7.0 \%$ in 1946. However, the contents of the diet changed with the economic recovery and improvements in the standard of living, and marked increases were observed particularly in the fat intake. Consequently, the percentage of fat in the total energy intake increased gradually to date, exceeding 20\% in 1973 and $25 \%$ in 1988 .

The incidence of coronary heart disease increases when the fat energy ratio exceeds $20 \%$ (85). Cancer was primarily stomach cancer and uterine cancer when the fat/energy ratio was $20 \%$ or less, but colon cancer, lung cancer, and pancreatic cancer increased as the fat/ energy ratio exceeded $20 \%$, with increases in prostate cancer in males and breast cancer in females. Thus, the disease structure changed as the fat/energy ratio increased. A fat/energy ratio of $25 \%$ is regarded as the maximum in dietary therapy (85).

As the fat/energy ratio has increased, the serum lipid levels have gradually increased in the entire population. In 1960, when the fat intake was $24.7 \mathrm{~g}$ (fat/energy ratio

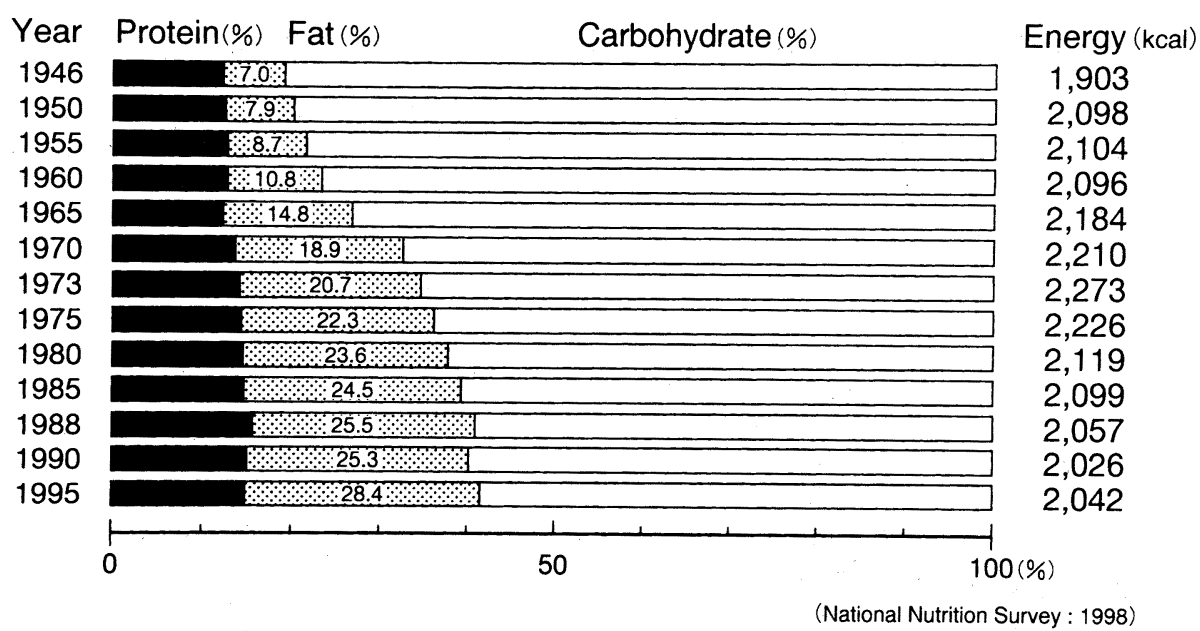

Fig. 13. Trends in dietary energy intake and the energy ratio in Japan. 
$10.6 \%)$, the mean total cholesterol level was $176 \mathrm{mg} / \mathrm{dl}$ $(4.55 \mathrm{mmol} / \mathrm{L})$, but the method for the assay of serum triglyceride level had not been developed (86). In 1970, when the fat intake was $46.5 \mathrm{~g}$ (fat/energy ratio $18.9 \%$ ), the total cholesterol level was $185 \mathrm{mg} / \mathrm{dl}(4.78 \mathrm{mmol} / \mathrm{L})$, and the triglyceride level was $104 \mathrm{mg} / \mathrm{dl}(1.17 \mathrm{mmol} / \mathrm{L})(87)$. In 1980, when the fat intake was $55.6 \mathrm{~g}$ (fat/energy ratio $23.6 \%$ ), the total cholesterol level was $189 \mathrm{mg} / \mathrm{dl}(4.89$ $\mathrm{mmol} / \mathrm{L})$, and the triglyceride level was $107 \mathrm{mg} / \mathrm{dl}(1.21$ $\mathrm{mmol} / \mathrm{L}$ ) (88). In 1990, when the fat intake became 56.9 $\mathrm{g}$ (fat/energy ratio $25.8 \%$ ), the total cholesterol level was $204 \mathrm{mg} / \mathrm{dl}(5.28 \mathrm{mmol} / \mathrm{L})$, and triglyceride level was 132 $\mathrm{mg} / \mathrm{dl}(1.49 \mathrm{mmol} / \mathrm{L})(89)$. If we keep eating foods as everybody else does, our serum lipid levels are likely to increase to $200 \mathrm{mg} / \mathrm{dl}(5.17 \mathrm{mmol} / \mathrm{L})$ for total cholesterol and above $130 \mathrm{mg} / \mathrm{dl}(1.46 \mathrm{mmol} / \mathrm{L})$ for triglycerides.

\section{Dietary habit and serum lipid levels}

Then, we studied the effects of the difference in the dietary habit, i.e. which of the Western-style diet and Japanese-style diet is preferred. The dietary habit may vary widely: Some people may have only 2 meals a day without breakfast, others may have restrictions about food items they eat such as vegetarianism, and others may eat out most of the time because of their social statuses such as being single or living separately from family. Among these factors, to evaluate the effects of the dietary style on the serum lipid levels, we directed our attention to which of the Japasese-style diet and Western-style diet is eaten more frequently. The dietary habit was classified according to the numbers of Japanese and Western meals the subjects ate during a given period. However, the definition of the Japanese and Western dishes is not always easy. For example, should steak cooked in a Japanese style, seasoned with soy sauce, and eaten with chopsticks be regarded as a Japanese dish from the way it is cooked and served or as a Western dish from the material? With these difficulties in mind, we tentatively classified dishes seasoned with soy sauce Japanese and those seasoned with a Western sauce Western.

We asked 176 patients with life-style-related abnormalities treated on the outpatient basis $(75$ males and 101 females; mean age $68 \pm 12$ years in males, $69 \pm 12$ years in females) to record the contents of their meals on any 3 consecutive days by their next visit. The patients were classified according to the number of Japanese meals they had in the 9 meals during 3 days. The number of Japanese meals was $0-3$ in 22 patients ( 15 males, 7 females), 4-6 in 104 (38 males, 66 females), and 7-9 in 50 (22 males, 28 females). They were tentatively called non-Japanese diet group, intermediate group, and Japanese diet group, respectively, and the serum lipid levels were compared among them (Fig. 14).

In the Japanese diet group, the mean total cholesterol level was $13 \mathrm{mg} / \mathrm{dl}(0.34 \mathrm{mmol} / \mathrm{L})(25 \mathrm{mg} / \mathrm{dl}$ or $0.64 \mathrm{mmol} /$ $L$ in males, $4 \mathrm{mg} / \mathrm{dl}$ or $0.10 \mathrm{mmol} / \mathrm{L}$ in females) lower, the
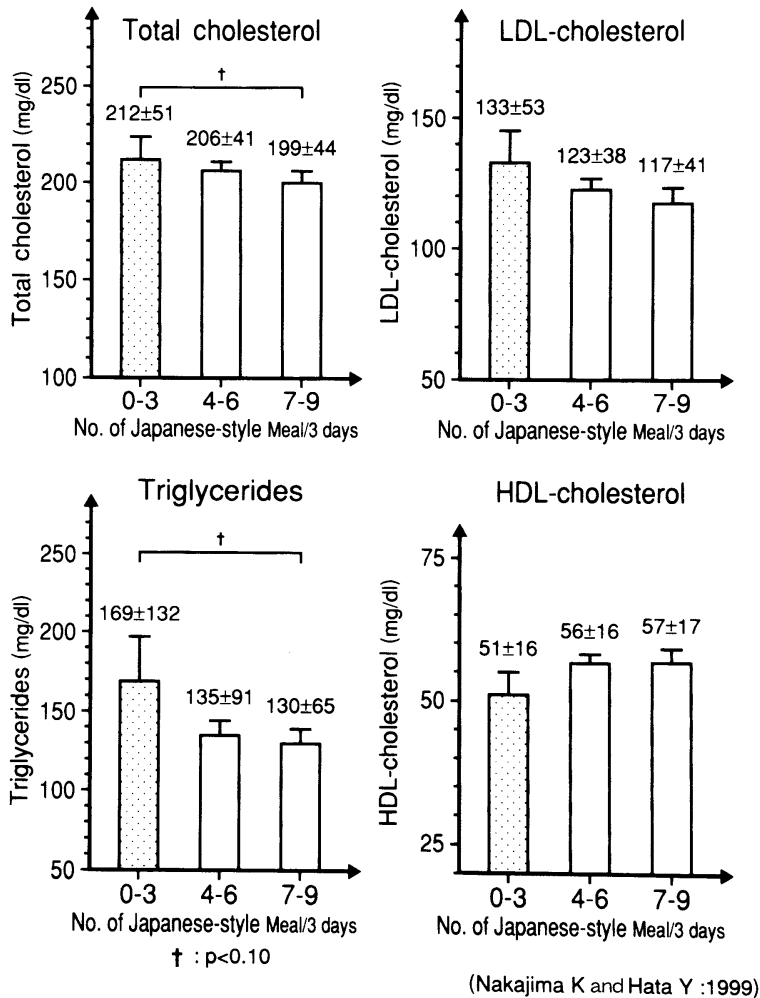

Fig. 14. Effects of Japanese-style diet on serum lipids and lipoproteins.

mean LDL-cholesterol level was $16 \mathrm{mg} / \mathrm{dl}(0.41 \mathrm{mmol} / \mathrm{L})$ (25 mg/dl or $0.65 \mathrm{mmol} / \mathrm{L}$ in males, $12 \mathrm{mg} / \mathrm{dl}$ or $0.31 \mathrm{mmol} /$ $L$ in females) lower, the triglyceride level was about 40 $\mathrm{mg} / \mathrm{dl}(0.45 \mathrm{mmol} / \mathrm{L})(63 \mathrm{mg} / \mathrm{dl}$ or $0.71 \mathrm{mmol} / \mathrm{L}$ in males only) lower, but the HDL-cholesterol level was about 5 $\mathrm{mg} / \mathrm{dl}(0.13 \mathrm{mmol} / \mathrm{L})(6 \mathrm{mg} / \mathrm{dl}$ or $0.16 \mathrm{mmol} / \mathrm{L}$ in males, 1 $\mathrm{mg} / \mathrm{dl}$ or $0.03 \mathrm{mmol} / \mathrm{L}$ in females) higher, than in the nonJapanese diet group as in Fig. 15. The Japanese diet group showed a good serum lipid profile, i.e. low total cholesterol, LDL-cholesterol, and triglyceride levels and a high HDL-cholesterol level, compared with the nonJapanese diet group.

Effects of such differences in the dietary habit on the serum lipid levels were compared among regions with different living environments, e.g. between cities and agricultural villages, between agricultural villages and fishing villages, and between the native Japanese and Japanese emigrants to the United States or Brazil. We could collect 11 research papers concerning 30 populations (90-100). Figure 15 summarizes the results.

These populations were classified into those of cities, agricultural villages, and fishing villages, and the mean serum lipid levels were compared. Eight populations (3,613 persons ; mean age 51 years) were regarded as city dwellers, 13 populations (5,364 persons; mean age 51 years) as agricultural village dwellers, and 9 populations $(1,071$ persons; mean age 52 years) as fishing village 

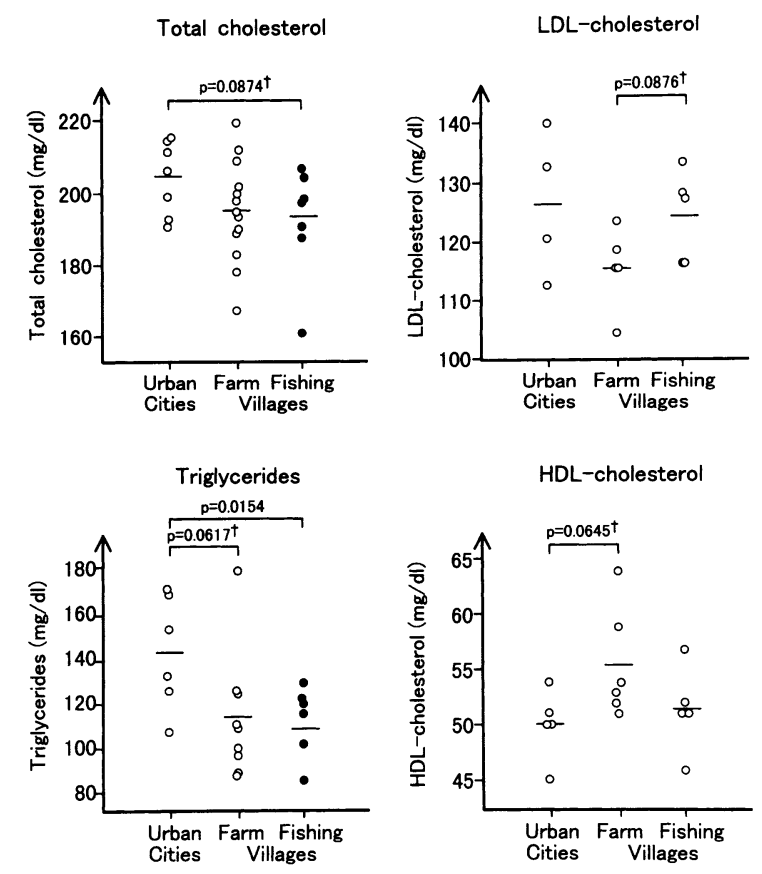

Study $: 11, n=10.066(49 y)), t: P<0.10$
$\Delta T C(U-F s)=\Delta T C(U-F m)=-10 \mathrm{mg} / \mathrm{dl}, \quad \Delta T G(U-F s)=\Delta T G(U-F m)=-30 \mathrm{mg} / \mathrm{dl}, \Delta H D L-c(U-F m)=5 \mathrm{mg} / \mathrm{dl}$

(Nakajima Kand Hata $Y:$ 1999)

Fig. 15. Difference in serum lipids and lipoproteins among dwellers in urban cities, farm and fishing villages in Japan.

dwellers. The total cholesterol level was lower in fishing villages than in cities, the triglyceride level was lower in agricultural villages and fishing villages than in cities, and the HDL-cholesterol level was higher in agricultural villages than in cities. The mean total cholesterol level was $10 \mathrm{mg} / \mathrm{dl}(0.26 \mathrm{mmol} / \mathrm{L})$ higher in cities than in fishing villages, the mean triblyceride level was $15 \mathrm{mg} / \mathrm{dl}(0.17$ $\mathrm{mmol} / \mathrm{L}$ ) higher in cities than in agricultural or fishing villages, and the mean HDL-cholesterol level was $5 \mathrm{mg} / \mathrm{dl}$ $(0.13 \mathrm{mmol} / \mathrm{L})$ lower in cities than in agricultural villages and $3 \mathrm{mg} / \mathrm{dl}(0.08 \mathrm{mmol} / \mathrm{L})$ lower in cities than in fishing villages. The serum lipid profile was better in agricultural villages than in cities and often in fishing villages than in agricultural villages.

Many factors are considered to be involved in these differences, but how much the traditional Japanese diet based on rice and fish is maintained cannot be disregarded as a key factor as suggested by the above observation that the frequency of Japanese-style meals affected the serum lipid pattern.

Figure 16 compares changes in the intakes of rice and fish by the Japanese with the intakes of meat and wheat as bread and noodles and the consumption of wheat for bread production based on the annual data of the Present State of Nutrition of the Japanese. The rice intake decreased each year from $369 \mathrm{~g} /$ day in 1940, markedly decreased in 1971 due to the bread-eating boom and in

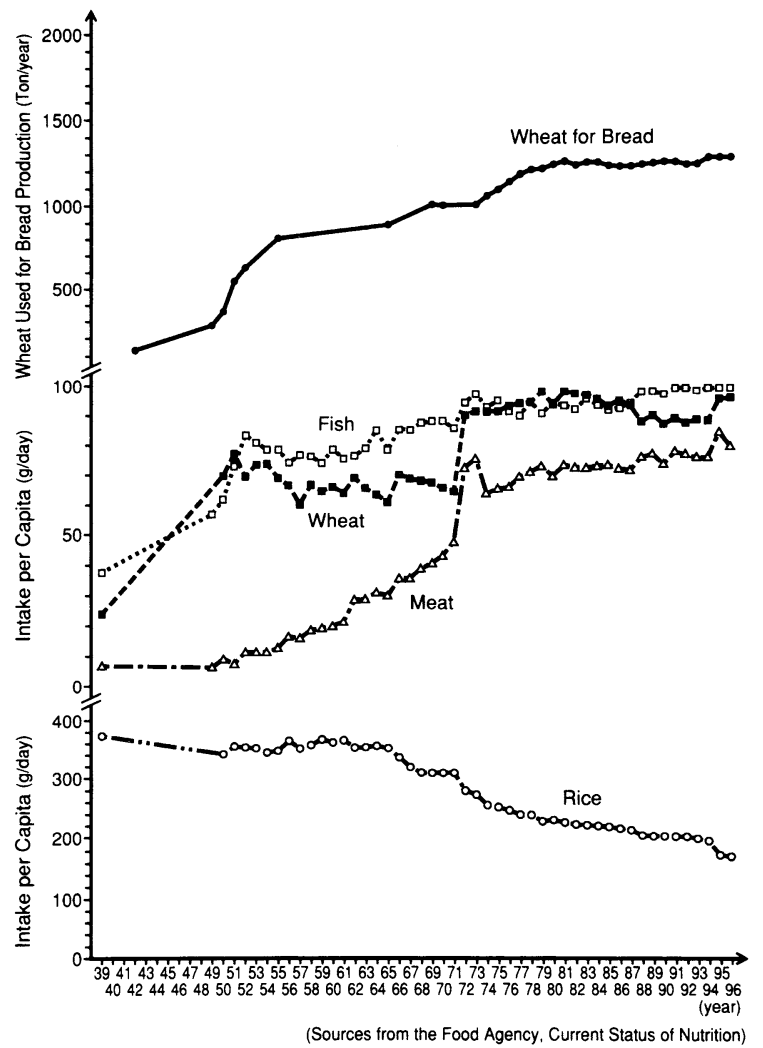

Fig. 16. Trends in daily intake of rice, fish, meat and wheat products, and the amount of wheat used for bread production

1994 due to the poor domestic crop and emergency import of foreign rice, and has recently reached $167 \mathrm{~g} /$ day. In contrast to the progressive decrease in the rice intake, the wheat intake showed a major increase with rapid increases in the meat consumption. Westernization of the Japanese diet accelerated after 1970.

In this trend, the fish consumption has continued to increase slightly and at least has not decreased. Thanks to this relatively high fish intake, the mortality rate due to coronary heart disease in Japan has been one-fifth that in the United States despite the facts that the difference in the mean serum cholesterol level between the Japanese and American populations is closing and that the relationship between the serum cholesterol level and the relative risk of coronary heart disease shows similar J-curves in both countries (101).

The effects of dietary fat on serum lipids are ascribed to fatty acids that constitute fat and to lipid-soluble components dissolved in dietary fat. Of various fat types, saturated fat increases the cholesterol level in general (102). Particularly, myristic acid $\left(\mathrm{C}_{14: 0}\right)$ contained in coconut oil and palmitic acid $\left(\mathrm{C}_{16: 0}\right)$ that abounds in palm oil stimulate cholesterol synthesis in the liver and increases the serum cholesterol level (103). Stearic acid $\left(\mathrm{C}_{18: 0}\right)$ is also a saturated fatty acid but does not affect the choles- 
terol level (103). Oleic acid $\left(\mathrm{C}_{18: 1}\right)$, which is contained abundantly in olive oil was considered not to affect the cholesterol level but was recently shown to reduce it (104).

Linoleic acid $\left(\mathrm{C}_{18: 2}\right)$, which is a polyunsaturated fatty acid contained at a high level in corn oil and safflower oil, is less valued today than it used to be, because it reduces the HDL-cholesterol level (105) as well as the total cholesterol level, and because it is readily converted to lipid peroxide (106). Eicosapentanoic acid (EPA, $\mathrm{C}_{20: 5}$ ), which is a highly polyunsaturated fatty acid contained at a high level in fish oil, reduces the serum triglyceride level by inhibiting triglyceride synthesis (107).

Fatty acids are also involved in genesis of atherosclerosis via their effects on platelets. Stearic acid $\left(\mathrm{C}_{18: 0}\right)$, which is a saturated fatty acid, has no effect on cholesterol but potently induces platelet aggregation (108). On the other hand, EPA $\left(\mathrm{C}_{20: 5}\right)$ inhibits platelet aggregation (109).

Therefore, coconut oil consists of saturated fat though it is derived from a plant, and EPA is a polyunsaturated fatty acid though it is derived from fish. Therefore, it is inappropriate to represent plant oil and animal fat by the names of saturated fat and unsaturated fat.

Among the components dissolved in oil and fat, cholesterol itself has the potent effect on the serum lipid levels. One hundred milligrams of dietary cholesterol increases the serum cholesterol level by $3 \mathrm{mg} / \mathrm{dl}(0.08 \mathrm{mmol} / \mathrm{L})$ (110).

In addition to fat, dietary fiber prevents the enterohepatic circulation of cholesterol by adsorbing bile acids and reduces the serum cholesterol level (111).

As shown in Fig. 17, the intake of fish affects the risk of cerebrovascular diseases and cardiac disorders including ischemic heart disease, and the total mortality rate. Data of surveys indicate that the mortality rate due to atherosclerotic disorders increases progressively as the fish intake is less frequent (112).

Dietary guidance or dietary therapy and serum lipid levels The effects of dietary guidance or treatment on serum

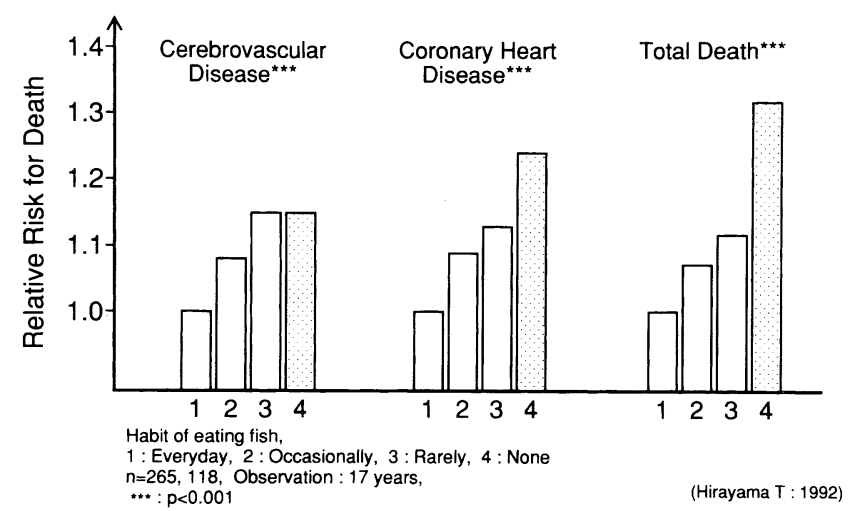

Fig. 17. Age-sex adjusted relative risk for atherosclerotic vascular disease and total death in accordance with fish eating habit in Japan.
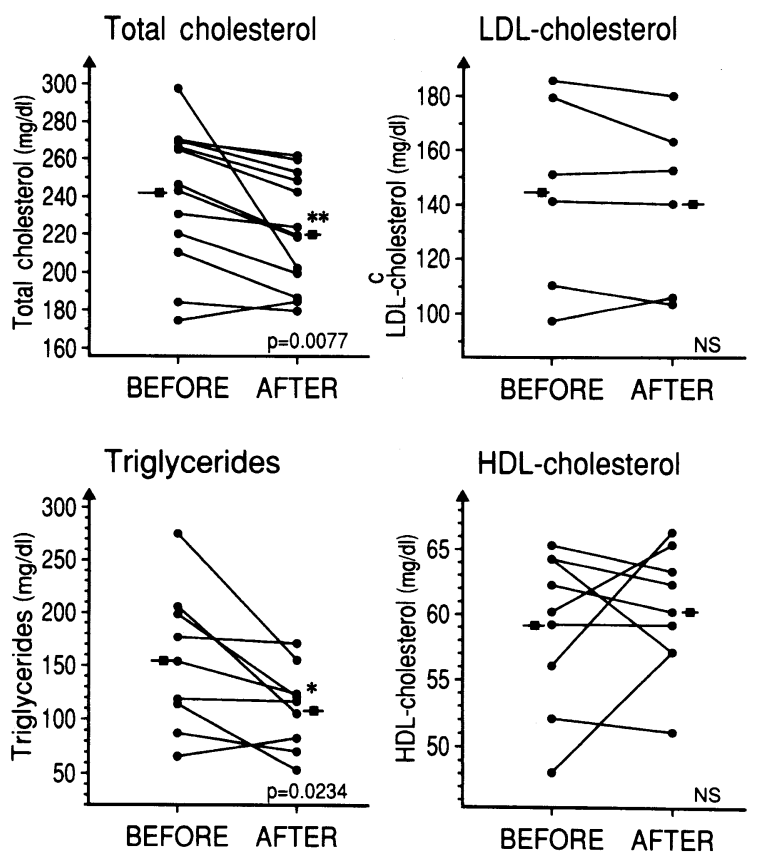

Study : 12, $\quad \mathrm{n}=585$ (m 160, f 425) (53 yo), $* p<0.05, \quad * * p<0.01$ $\Delta \mathrm{TC}=-20 \mathrm{mg} / \mathrm{dl}, \Delta \mathrm{TG}=-40 \mathrm{mg} / \mathrm{dl}, \Delta \mathrm{HDL}-\mathrm{C}=1 \mathrm{mg} / \mathrm{dl}$

(Nakajima K, Hata Y. : 1999)

Fig. 18. Effects of dietary treatment on serum lipids and lipoproteins.

lipid levels were evaluated in individuals who were diagnosed to be hyperlipidemic and received dietary guidance or dietary therapy at outpatient clinics of hospitals, health care centers of offices and schools, and local health centers. Twelve research papers concerning 13 groups (113-124) could be collected as in Fig. 18. The total number of subjects was 585 (160 males and 425 females), and their mean age was 53 years. The followup period after guidance varied widely from 8 weeks to 52 weeks with a mean of 35 weeks. In a long follow-up of 52 weeks, intermediate guidance or examination was performed at 3 months (12 weeks) and 6 months (24 weeks). Since the duration of the dietary therapy varied in the studies reviewed, precise evaluation of the effect of dietary therapy was impossible. However, the total cholesterol level decreased by about $20 \mathrm{mg} / \mathrm{dl}(0.52 \mathrm{mmol} / \mathrm{L})$, the triglyceride level decreased by $40 \mathrm{mg} / \mathrm{dl}(0.45 \mathrm{mmol} /$ $\mathrm{L})$, and the HDL-cholesterol level increased by $5 \mathrm{mg} / \mathrm{dl}$ $(0.13 \mathrm{mmol} / \mathrm{L})$ in the mean value as observed in Fig. 18.

"Don't-ism", which used to be the primary style of dietary guidance, has mostly disappeared, and control of the energy intake was stressed in half of the studies reviewed. In the remaining half, also, restriction of the fat intake, reduced intake of cholesterol from foods, increased intake of vegetables, and more physical activity were major contents of the guidance. The fish intake was encouraged in 2 studies. 


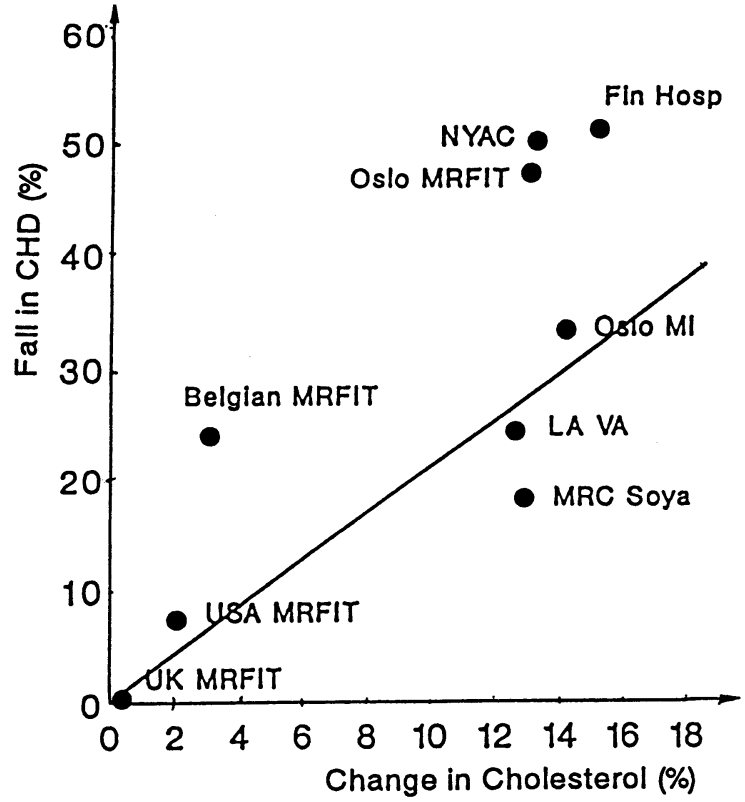

Fig. 19. Relationship between the changes in serum cholesterol induced by diet and the decline in coronary heart disease in various dietary intervention trials (cited from reference 125 with permission).

However, dietary guidance given at outpatient clinics of hospitals or as part of company health management programs was no more than oral transmission of food information and dietary regimens, and its actual practice is left to each patient or employee. For this reason, the effect of dietary guidance can be inconsistent or insufficient. However, dietary therapy is aimed at correction of improper habits that have caused abnormal serum lipid levels, and is a proper and essential approach, and the final aim of cholesterol lowering at prevention of coronary heart disease has been positively achieved as in Fig. 19 by a meta-analysis of various dietary intervention trials (125). One percent reduction in serum cholesterol induces $2 \%$ reduction in primary episode of coronary heart disease as in the case of the intervention trials by using cholesterol lowering drugs.

\section{Discussion}

This article evaluates what effects the life-style of the Japanese, which has unprecedentedly changed in the second half of the 20th century with the drastically altered living environment, have exerted and are exerting on serum lipids and lipoproteins, metabolic parameters most closely related to atherosclerotic disorders (3), which have come to account for about one-third of deaths of the Japanese (2).

Documents and materials were hunted over 50 years up to the period immediately after the war, and research papers published after 1966 found in the MEDLINE and those published after 1987 found in Igaku Chuo Zasshi were collected as a database. These materials were reviewed and discussed from the viewpoints of 1) problems of life-style-related disorders and living-environment -related disorders, 2) characteristics of the Japanese life -style and its effects on the serum lipid levels, and 3) the significance of correction of abnormalities in serum lipid levels associated with improvements for the life-style for prevention of atherosclerotic disorders.

\section{Problems of life-style-related diseases and living-envi- ronment-related disorders}

The life-style is a pattern of behavior acquired through our living in the society and fixed gradually by repetition to which we have been so accustomed that we can routinely perform it with little effort and obtain self-satisfaction through its execution. The life-style can take extremely diverse forms according to the nature of the family and work environments, individual preferences and values, and associated differences in time allotment to different activities in living. In a broader perspective, however, the life-style is inevitably restricted by the time and space of one's living, i.e. by the historical and environmental frameworks of one's life. In other words, it is allowed to have individual diversity within the limits of the living environment.

In Japan, which has accomplished economic development and improvements in the standard of living during the postwar decades and joined leading industrialized countries, a unique living environment has been formed, and the life-style repeated wherein has exerted similar effects on the body and mind of those living in it. The life-style is individually diverse and multifarious, but it may be classified into several types again in a broader perspective. For example, its effects on physical health may be summarized as the effects of smoking, drinking, physical activities or exercise, and diet or nutrition (1). In other words, accumulation of habitualized behavior including smoking, drinking, lack of exercise, and dietary contents has caused particular distortions of the body and induced specific disease groups until they are recognized as life-style-related disorders. From a different viewpoint, they may be regarded as living-environment-related disorders induced by the living environment of the Japanese in the second half of the 20th century.

The physical abnormalities observed in and after middle age that emerged under the effects of such living environment and life-style came to be called "adult diseases" as the Ministry of Health and Welfare established the Committee for the Prevention of Adult Diseases (1) in 1956 and measures were taken to prevent stroke, cancer, and cardiac disorders, which began to prevail in those days. Hypertension, diabetes mellitus, and hyperlipidemia were later added as "adult diseases" that require preventive measures (1). However, the situation advanced to a stage where effects of the living environment and life- 
style became apparent even in children and elementary school pupils until the use of the term "adult diseases in children" became necessary. This term, however, is clearly self-contradicted. To solve this contradiction and to better represent the nature of the situation, the term "life-style-related diseases or disorders" was introduced in the White Paper of Health and Welfare in 1997 (1).

This term is more appropriate than adult diseases but still has the connotation that one contracts life-stylerelated disorders, because one unwisely repeats inadequate behavior in the living-environment. That is, the term suggests that the individual is totally responsible for the disorders. While these disorders are certainly caused by the lack of protection or restriction in the life of the individual, they are equally certain to disappear if the individual does not live in the environment that has nurtured these abnormalities. In this sense, measures for prevention of life-style-related disorders must include measures to improve the living environment. Emphasizing self-management, group guidance, and outpatient care with no measures in this respect would be ineffective and wasteful in labor and cost. This seems to be typically true of the problem of smoking. The concept of life-style-related disorders is considered to have aspects that require their redefinition as living-environment-induced disorders.

Effects of the life-style on the serum lipid levels and their characteristics

In this study, papers on the effects of smoking, drinking, exercise, and diet among factors of life-style on the serum lipid levels were collected primarily in the Japanese literature, and meta-analysis was performed with the data. Concerning exercise and diet, the results of studies of
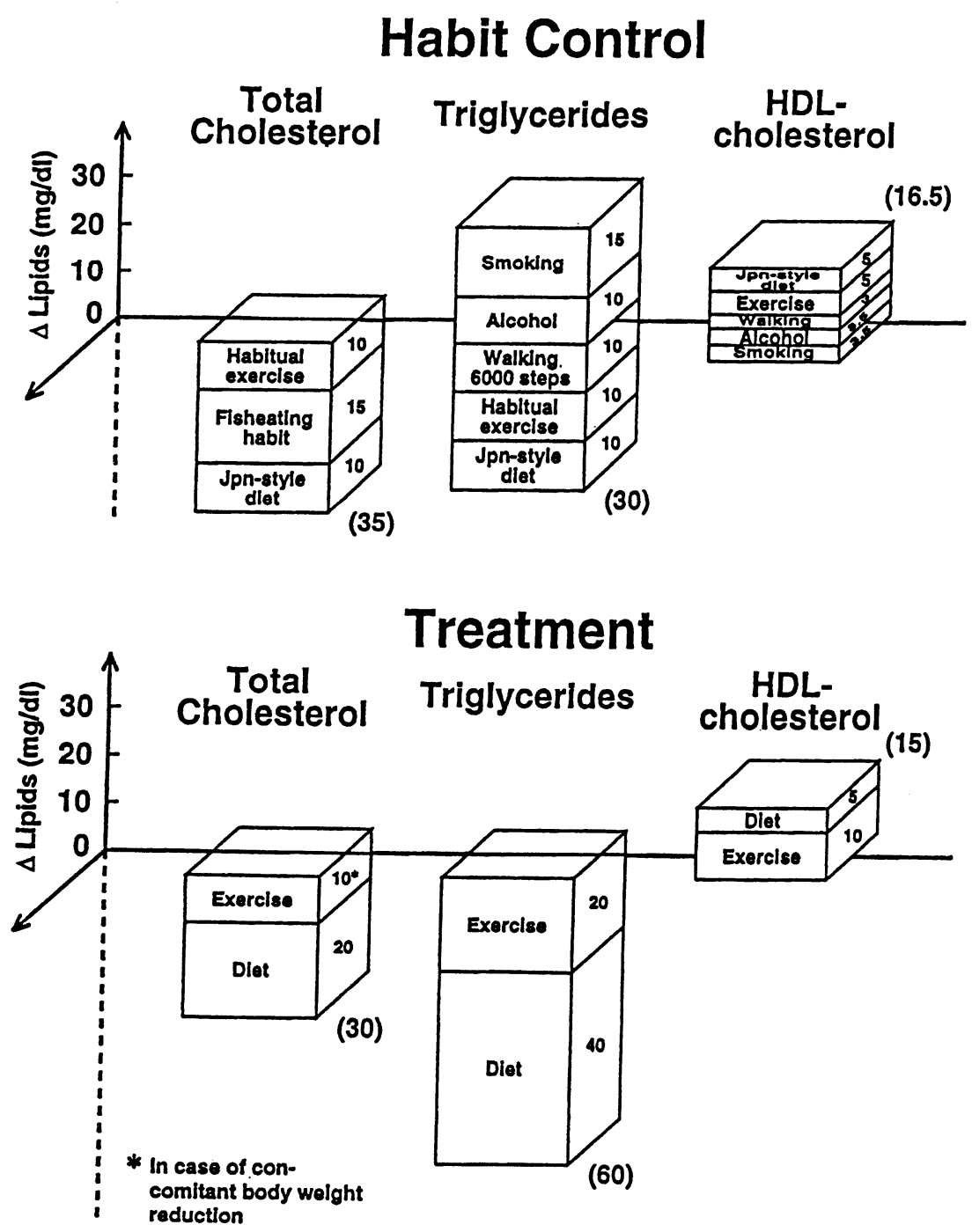

(Hata Y and Nakajlma K : 1999)

Fig. 20. Potential effects of life-style change on serum lipids and lipoproteins. 
therapies that can be performed in the living environment of Japan were collected, and their procedures and magnitude of their effects were studied. Fig. 20 summarizes the results in a square column graph. Factors of the lifestyle and treatments are indicated on the front surfaces of the columns, and the values representing the possibility of effectiveness are shown on the lateral sides.

The following points were noticed in the process of meta-analysis of these data: 1) Among the factors of life-style, drinking and exercise, and smoking in part of the subjects, affect the serum lipid levels first by increasing the triglyceride level. 2) Then, they decrease HDLcholesterol in reciprocal with the triglyceride level. 3) Smoking has been considered to decrease the HDLcholesterol level alone. However, when we analyze the effect of smoking on serum triglycerides only in nondrinkers to exclude the effect of drinking which often goes with smoking, it has become clear that smoking by itself increases the triglyceride level, independently of drinking in proportion to the cigarettes smoked. 4) In other words, triglycerides and $\mathrm{HDL}$-cholesterol respond well and quickly to restriction of alcohol intake, smoking and exercise therapy. 5) On the other hand, changes in total cholesterol and LDL-cholesterol appear only after continuation of exercise therapy intensive enough to cause reduction in the body weight for a considerable period. 6) The total cholesterol and LDL-cholesterol levels respond more sensitively to dietary therapy. The therapeutic effect of an energy-restricted diet that would cause a reduction in the body weight is notable. A restriction of the fat intake and a reduction in the dietary cholesterol intake are also effective. 7) An energy-restricted diet (restriction mainly of the fat intake) was effective for improving the triglyceride as well as cholesterol level and increased the HDL-cholesterol level.

As for quantitative effects of correction of the life-style on the serum lipid levels, the serum cholesterol level will be potentially reduced by a total of about $25 \mathrm{mg} / \mathrm{dl}(0.65$ $\mathrm{mmol} / \mathrm{L}$ ) as shown in the left column of the upper panel of Fig. 20, by increasing the frequency of Japanese-style meals and the intake of fish.

The triglyceride level is expected to decrease by a total of about $30 \mathrm{mg} / \mathrm{dl}(0.34 \mathrm{mmol} / \mathrm{L})$ as in the central column of the upper panel of Fig. 20 by abstaining from smoking, reducing alcohol intake, walking at least 6,000 steps/day, regularly practicing mild to moderate exercise, and maintaining a more Japanese-style diet.

The HDL-cholesterol level is expected to be increased by about $16.5 \mathrm{mg} / \mathrm{dl}(0.43 \mathrm{mmol} / \mathrm{L})$ as in the right column of the upper panel of Fig. 20 by abstaining from smoking, restricting the alcohol intake within the recommended limits, walking 6,000 or more steps/day, practicing light to moderate exercise at least 3 times a week, and maintaining a Japanese diet.

As for the quantitatively effects of intensive exercise and dietary treatments, the total cholesterol level may also be decreased by nearly $30 \mathrm{mg} / \mathrm{dl}(0.78 \mathrm{mmol} / \mathrm{L})$ as in the left column in the lower panel of Fig. 20 by continuation of exercise therapy intensive enough to cause a reduction in body weight, restricting the caloric intake to about 25 $\mathrm{kcal} / \mathrm{kg}$ body weight and reducing the fat intake (126-128).

An aggressive exercise and dietary treatments may result in a reduction of $60 \mathrm{mg} / \mathrm{dl}(0.68 \mathrm{mmol} / \mathrm{L})$ in serum triglycerides as shown in the column in the center of the lower panel of Fig. 20 by moderate or more intense exercise combined with a sustained energy-restricted diet of $30 \mathrm{kcal} / \mathrm{kg}$ or less.

As for the HDL level, an increase of about $15 \mathrm{mg} / \mathrm{dl}$ $(0.39 \mathrm{mmol} / \mathrm{L})$ can be expected as in the right column of the lower panel of Fig. 20 by a combination of moderate or more intense exercise and an energy-restricted diet of about $25 \mathrm{kcal} / \mathrm{kg}$.

These possibilities of improvements in the serum lipid levels are based on the assumptions that the modifications of the life-style can be complied with and that exercise and dietary therapies are sure to work. It is true that not all subjects can perform the therapies exactly as required and not all effects appear as expected. However, what and how much effects improvements in the life-style or exercise and dietary therapies can exert have not been shown systematically to date. The present review of the literature and the results of meta-analysis are considered to be significant in that they fill this deficiency.

\section{Significance of improvements in the serum lipid levels by correction of the life-style in prevention of atheroscle- rotic disorders}

As the dietary fat intake increased, and as the percentage of fat in the total energy intake increased in Japan (Fig. 13), the serum lipid levels of the Japanese have increased during the past 30 years by $28 \mathrm{mg} / \mathrm{dl}(0.73$ $\mathrm{mmol} / \mathrm{L}$ ) at least in cholesterol (Fig. 14). The increases in the serum lipid levels were not followed immediately by an increase in the mortality rate due to atherosclerotic disorders, but subjective symptoms of coronary heart disease and electrocardiographic signals indicating ischemic changes usually appear only after narrowing of the arterial lumen has reached about $75 \%$ (129), unless unstable lipidrich plaques do not rapture suddenly. In the present stage, narrowing of arterial lumen is considered to be stealthily progressing at levels less than $75 \%$ in a large percentage of the Japanese. In fact, comparison of the extent of coronary atherosclerosis in autopsied bodies of individuals aged 40 years or below between 1985 and 1996 indicated that the coronary lesion of atherosclerosis extended 2.8 times in the tissue level during the 16 years though the subjects remained asymptomatic (130). Unless measures are taken against this lurking progression of atherosclerosis, major problems may arise in a near future in the forms of diseases of individual people and sociomedical problems. 
Research world-wide has indicated that the best preventive measure against atherosclerosis is early detection and elimination of its risk factors (131). Among the risk factors of atherosclerosis, abnormalities of the serum lipid levels are known to be most directly linked with atherosclerosis and are closely related to the life-style (131).

Elimination of risk factors or correction of abnormal serum lipid levels by improving the life-style has been suggested to be important, but its practical effectiveness has been considered questionable. One of its reasons was that how much improvement can be expected in the serum lipid levels by how much correction of the life-style has not been shown clearly. In this study, research results in Japan have been compiled, and the degrees of correction of the life-style were systematically related to the degrees of improvements in the serum lipid levels for the first time as in Fig. 20.

The Japan Atherosclerosis Society Guideline for Diagnosis and Management of Hyperlipidemias for Prevention of Atherosclerosis (101) emphasizes that non-drug therapy by correction of the life-style must be tried before the use of drugs. The results of this study suggest that a nondrug therapy can be sufficiently effective, and provide a supportive evidence for the utility of non-drug therapy in the guideline.

In addition, the serum cholesterol level, for example, could be reduced as much as $20 \mathrm{mg} / \mathrm{dl}(0.52 \mathrm{mmol} / \mathrm{L})$ by dietary therapy. By studies overseas, a decrease in the serum cholesterol level by dietary therapy has been shown to reduce the risk of the primary episode of coronary heart disease in the relationship of $1 \%$ lowering in cholesterol inducing $2 \%$ reduction in initial event of coronary heart disease as does a similar decrease in serum cholesterol induced by drug therapy $(125,132,133)$. It has been demonstrated that a sustained reduction in the serum cholesterol level by $10 \%$ with either a diet or a drug leads to a $20 \%$ reduction in the risk of the initial episode of coronary heart disease and that a $15 \%$ reduction in the cholesterol level leads to a $30 \%$ reduction in the risk (125, 132, 133). According to this observation, even a small decrease in the cholesterol level due to non-drug therapy has an extra effect over the effect of drug-therapy in an additive manner. Therefore, even if the effect of correction of the life-style per se may be small, it can still contribute to the overall effect of the therapy.

In consideration of the findings that the effect of correction of the life-style appears first in the triglyceride and HDL-cholesterol levels, that the total cholesterol level can be significantly reduced by dietary therapy, and improvements can be accomplished only by intensive exercise therapy, one may wonder if the general approach of correcting the life-style may be unnecessary for the treatment of hypercholesterolemia. Two points are worth mentioning concerning this argument. First, abnormalities of the serum lipid levels are related to one another at their base, and an improvement in the triglyceride level serves as the basis for the adjustment of the entire lipid metabolism of the body. Therefore, an improvement in the triglyceride level is considered to improve the basis of lipid metabolism although it may not directly lead to improvements in the total cholesterol or LDL-cholesterol level. Secondly, the relationship between triglycerides and atherosclerosis has not been sufficiently established, but triglycerides are likely to be a pathogenic factor of atherosclerotic disorders independent of cholesterol and to be involved in multiple risk factor syndromes such as "syndrome X" (134) or "deadly quartet" (135). Therefore, correction of the serum level of triglycerides, which play a major role in these disorders, is quite meaningful.

Through this review, we systematically clarified the relationships of distortions of the life-style with the serum lipid levels and the effects of their correction. These observations are considered to sufficiently indicate the effectiveness and significance of treatments, particularly, non-drug therapies, for hyperlipidemias.

Acknowledgment: The authors acknowledge that this study is supported in part by the grant in aid for scientific research given by Danone Institute Japan, 1999.

\section{References}

(1) White Paper of Health and Welfare, 1997 Ed, For The Improvement of "Health" and "Quality of Life". ed by the Ministry of Health and Welfare, pp 50-79, Society for the Study of Health and Welfare Problems, Tokyo, 1997

(2) Trends of Hygiene of the Japanese: Indices of Health and Welfare, 47 (Special Issue) : 86-94, 2000

( 3 ) Poulter NR and Chapman N: Epidemiology of atherosclerosis. In: Lipoproteins in Health and Disease. ed by Betteridge DJ, Illingworth DR, and Shepherd J, pp 541-573, Arnold, London, 1999

(4) Health Service Bureau, Ministry of Health and Welfare: Present Nutritional Status of the Japanese. Results of the 1998 National Nutritional Survey, pp 29-64, Daiichi Shuppan, Tokyo, 2000

\section{Smoking and Serum Lipids}

( 5 ) Yamori Y, Kihara M, Horie R, Note S, Tsunematsu T, and Fukase $\mathrm{M}$ : Epidemiological analysis on the mechanism of cigarette smoking as a risk factor in cardiovascular disease. Jpn Circ J, 44: 965-970, 1980

(6) Yamamoto Y: Smoking, drinking, and hyperlipidemia. Rinsho Eiyo, 58: 680-684, 1981

(7) Takashima Y : A study of serum lipids from the viewpoint of health screening. Part 1; Significance of the serum, HDL-cholesterol level in health education. Jpn J Public Health, 29 : 393-401, 1982

( 8 ) Toyoshima H, Hayashi C, Miyanishi K, Wakai S, Enoki $\mathrm{S}$, Kumagai $\mathrm{H}$, and Uemura $\mathrm{K}$ : Effects of serum lipids, smoking, and drinking on the serum vitamin $A$ and vitamin E concentrations. Jpn J Hygiene, 44: 659666, 1989

(9) Mitsuzawa KI, Matsuki H, Kasuga H, Yokokaya K, and Hinohara S: An epidemiological study of HDL-cholesterol with smoking and obesity in healthy subjects. 
Jpn J Hygiene, 44 : 725-732, 1989

(10) Momose $Y$ : Relationships of the serum total cholesterol and HDL-cholesterol levels with the life-style in farmers and non-farmers. J Jpn Ass Rural Med, 40 : 1007-1018, 1992

(11) Nishizawa $T$ and Tanimoto $K$ : Effects of routine alcohol intake and smoking on the serum lipid and uric acid levels. Purine-Pyrimidine Metabol, 17: 75-79, 1993

(12) Yamasaki R, Miyoshi T, Imaki $M$, and Nakamura T: Evaluation of the effects of various factors on the serum triglyceride level in young adults. Tohoku $\mathrm{J}$ Exp Med, 41: 17-30, 1994

(13) Sakuta H, Yamagishi Y, Miura C, Hanada A, Suzuki T, and Nakagawa $\mathrm{K}$ : Smoking as a health-damaging factor: Relationships with the blood pressure, liver function, and serum lipid and uric acid levels. Natl Defense Med J, 42 : 459-464, 1995

(14) Inoue S, lida N, Waku Y, Bessho Y, Dote Y, Nishiura K, and Kono $\mathrm{K}$ : Life-style and periodic health screening. J Osaka Med Coll, 56 : 8-14, 1996

(15) Uemura S, Saijo C, Murayama R, Kuriyama T, Koyama $\mathrm{M}$, Takagi $\mathrm{H}$, and Machida $\mathrm{K}$ : Relationships of the lifestyle and social net-work with blood pressure and serum lipids in the elderly. $\mathrm{J} J p n$ Ass Cerebro-Cardiovasc Dis Control, 50: 1057-1066, 1996

(16) Imamura H, Tanaka K, Hirae C, Futagami T, Yoshimura Y, Uchida K, Tanaka A, and Kobata D : Relationship of cigarette smoking to blood pressure and serum lipids and lipoproteins in men. Clin Exp Phamacol Physiol, 23: 397-402, 1996

(17) Kushima K, Izumi T, Sakai M, Sato H, and Takamoto N : Effects of the smoking habit on the serum lipid levels in working middle-aged males. Jpn J Physical Education, 41: 463-473, 1997

(18) lida $Y$ : A model for prediction of laboratory results using generalized regression analysis. St Marianna Med J, 25 : 587-598, 1997

(19) Utsunomiya C, Horie M, Miyazaki S, Oozono Y, Wakabayashi $M$, and Okawa $H$ : Relationships of the serum LDL cholesterol level (direct method) with smoking and drinking habits. J Jpn Ass Industrial Health, 40: 594, 1998

(20) Takanari $\mathrm{H}$, Takano $\mathrm{T}$, and Ito $\mathrm{Y}$ : Effects of smoking on the white blood cell count and serum lipid levels. $J$ Health Insurance Med, 38 : 16-20, 1998

(21) McCall MR, van den Berg JJM, Kyupers FA, Tribble DL, Krauss RM, Knoff LJ, and Forte TM: Modification of LCAT activity and HDL structure. New links between cigarette smoke and coronary heart disease risk. Arterioscler Thromb, 14: 248-253, 1994

(22) Yokode M, Kita T, Arai H, Kawai C, Narumiya S, and Fujiwara $\mathrm{M}$ : Cholesterol ester accumulation in macrophages incubated with low density lipoprotein pretreated with cigarette smoke extract. Proc Natl Acad Sci USA, 85 : 2344-2348, 1988

(23) Harats D, Ben-Naim M, Dabach Y, Hollander G, Stein $O$, and Stein $Y$ : Cigarette smoking renders LDL susceptible to peroxidative modification and enhanced metabolism by macrophages. Atherosclerosis, 79: 245-252, 1989

(24) Nagano $\mathrm{Y}$, Arai H, and Kita T: High density lipoprotein loses its effect to stimulate efflux of cholesterol from foam cells after oxidative modification. Proc Natl
Acad Sci USA, 88 : 6457-6461, 1991

(25) Hirayama $T$ : Smoking and disease-A recapitulation of epidemiological studies on a large cohort. Pharma Medica, 12 : 19-31, 1994

(26) Dawber TR: Tobacco and cardiovascular disease. In: The Framingham Study-The Epidemiology of Atherosclerotic Disease. pp 172-189, Harvard Univ Press, Cambridge, Massachusetts, 1980

(27) Freund KM, Belanger AJ, D'Agostino RB, and Kannel WB: The health risks of smoking. The Framingham Study: 34 years follow-up. Ann Epidemiol, 3: 417424, 1993

(28) Wolf PA, D'Agostino RB, Kannel WB, Bonita R, and Belanger $\mathrm{AJ}$ : Cigarette smoking as a risk factor for stroke. JAMA, 259: 1025-1029, 1988

\section{Alcohol and Serum Lipids}

(29) Koga T: Alcohol and metabolic systems of the body: Lipids. In : Liver and Alcohol, ed by Hirayama $C$ and Takada A, pp 56-65, Chugai Igaku-sha, Tokyo, 1986

(30) Handa K, Sasaki J, Saku K, Kono S, and Arakawa K: Alcohol consumption, serum lipids and severity of angiographically determined coronary artery disease. Am J Cardiol, 65 : 287-289, 1990

(31) Ishida K, Yamada H, Koide K, Ishida K, Kubo K, Ishibashi $F$, and Takashina S: A study of drinking habits and health in agricultural and fishing villages. Effects drinking on the liver, spleen, and carbohydrate and lipid of metabolism. J Jpn Ass Rural Med, 40: 12-24, 1991

( 32 ) Koyama H, Hosokai H, Tamura S, and Satoh H: Positive association between serum zinc and apolipoprotein A-II concentrations in middle-aged males who regularly consume alcohol. Am J Clin Nutr, $57: 657$ 661, 1993

(33) Ishikawa S, Nishiwaki M, Suzukawa M, Tomiyasu K, Yamashita T, Yoshida H, Nishio E, Hosoai H, Shigeru H, Ito T, Nakajima K, Higashi K, Nohmi M, Miyagi E, Kondo $\mathrm{K}$, and Nakamura $\mathrm{H}$ : Effects of alcohol on serum lipids, especially triglycerides. J Jpn Soc Clin Nutr, 16:8-12, 1994

(34) Choudhurg SR, Ueshima H, Kita Y, Kobayashi KM, Okayama A, Yamakawa M, Hirao $Y$, Shikawa $M$, and Miyoshi $Y$ : Alcohol intake and serum lipids in a Japanese population. Int J Epidemiol, 23 : 940-947, 1994

(35) Nishiwaki $M$, Ishikawa $T$, Ito $T$, Shigi $H$, Tomiyasu $K$, Nakajima K, Kondo K, Hashimoto H, Saitoh K, Manabe $\mathrm{M}$, Miyajima $\mathrm{E}$, and Nakamura $\mathrm{H}$ : Effects of alcohol on lipoprotein lipase, hepatic lipase, cholesterol ester transfer protein, and lecithin cholesterol acyltransferase in high-density lipoprotein cholesterol elevation. Atherosclerosis, 111: 99-109, 1994

(36) Araki K, Fukase O, Yamamoto A, Fujiwara T, Murayama $\mathrm{H}$, Yamaguchi $\mathrm{H}$, Inagaki $\mathrm{H}$, and Okochi $\mathrm{T}$ : Relationships of serum lipid peroxides (TBA value) with smoking, drinking, frequencies of intakes of various foods, and serum vitamin $C$ and vitamin $E$ levels observed in recipients of comprehensive medical examinations. Jpn J Public Health, 41: 311-321, 1994

(37) Kitamura A, Iso H, Sato S, lida M, Naito $Y$, Kiyama M, Okamura T, Nakagawa Y, Shimamoto T, Sankai T, Konno $\mathrm{H}$, and Komachi $\mathrm{Y}$ : An epidemiologic evaluation of the relationship between the alcohol intake and 
physical findings in regional and occupational groups. Jpn J Public Health, 43: 86-101, 1996

( 38 ) Ishimitsu T, Yoshida K, Nakamura M, Tsukada K, Yagi $\mathrm{S}$, Ohrui M, Hisauchi T, and Matsuoka $\mathrm{H}$ : Effects of alcohol intake on organ injuries in normotensive and hypertensive human subjects. Clin Sci, 93 : 541-547, 1997

(39) Yuda K: Changes in the nutritional intakes and intakes of various food groups associated with drinking and their relations with the results of cardiovascular examinations. J Jpn Ass Cerebro-Cardiovasc Dis Control, 33: 186-197, 1998

(40) Taguchi K, Hirose H, Shimada K, Kimura N, Genyo M, Morimasa A, Waiuchi H, Minamisato S, and Saito I: Relationship between the body fat ratio at periodical examination and life-style in school teachers. Keio Hoken Kenkyu, 16 : 50-54, 1998

(41) Nagaya $T$, Yoshida $H$, Takahashi $H$, Matsuda $Y$, and Kawai M : Dose-response relationships between drinking and serum tests in Japanese men aged 40-59 years. Alcohol, 17 : 133-138, 1999

(42) Sane T, Nikkila EA, Taskinen MR, Valimaki M, and Yleikahri R: Accelerated turnover of very-low-density lipoprotein triglycerides in chronic alcohol users. A possible mechanism for the up-regulation of highdensity lipoprotein by ethanol. Atherosclerosis, 53: 185-193, 1984

(43) Wolfe BM, Havel JR, Marliss EB, Kane JP, Seymour J, and Ahuja SP : Effects of three-day fast and of ethanol on splanchnic metabolism of FFA, amino acids, carbohydrates in healthy young men. J Clin Invest, 57: 329-340, 1976

(44) Lieber CS, Jones DP, Mendelssohn J, and DeCarli LM : Fatty liver, hyperlipidemia and hyperuricemia produced by prolonged alcohol consumption, despite adequate dietary intake. Transact Ass Amer Physicians, 76 : 289-300, 1963

(45) Mordasini R, Kaffarnik H, Schneider J, and Riesen W : Alcohol and plasma lipoproteins in acute and long-term studies. Schweiz Med Wochenschr, 112: 1928-1931, 1982

(46) Haskell WL, Camargo C Jr, Williams PT, et al: The effect of cessation and resumption of moderate alcohol intake on serum high-density lipoprotein subfractions. A controlled study. N Engl J Med, 310: 805-810, 1984

(47) Yano K, MacLean CJ, Reed DM, Shimizu Y, Sasaki H, Kodama K, Kato $\mathrm{H}$, and Kagan $\mathrm{A}$ : A comparison of the 12 -years mortality and predictive factors of coronary heart disease among Japanese men in Japan and Hawaii. Am J Epidemiol, 127 : 476-487, 1988

(48) Blackwelder WC, Yano K, Rhoads GG, Kagan A, Gordon T, and Palesch Y : Alcohol and mortality: The Honolulu Heart Study. Am J Med, 68: 164-169, 1980

(49) Konishi M, Ito M, Naito C, Terano A, Takayama $Y$, Ito $H$, Yutani C, Ito M, Kojima S, Shimamoto T, Inada H, Doi M, Iso $\mathrm{H}$, Sato $\mathrm{S}$, Kitamoto $\mathrm{A}$, and Komachi $\mathrm{Y}$ : The trend of coronary heart disease and its risk factors based on epidemiological investigation. Jpn Circ J, 51: 319324, 1987

(50) Miller GJ and Miller NE: Plasma-high-density-lipoprotein concentration and development of ischemic heart disease. Lancet, i : 16-19, 1975

\section{Exercise and Serum Lipids}

(51) Tanabe $\mathrm{Y}$, Sasaki J, Urata H, Kiyonaga A, Tanaka H, Shindo $M$, and Arakawa $\mathrm{K}$ : Effect of mild aerobic exercise on lipid and apolipoprotein levels in patients with essential hypertension. Jpn Heart J, 29: 199206, 1988

(52) Sasaki J, Tanabe Y, Tanaka H, Saku K, Shindo M, and Arakawa $\mathrm{K}$ : Elevated levels of $\mathrm{HDL}_{2}$-cholesterol and apo A-I in national class Japanese male marathon runners. Atherosclerosis, $70: 175-177,1988$

(53) Kobayashi $\mathrm{S}$ : Exercise and prevention of nutritionrelated disorders : Effects of exercise on metabolism of lipids and carbohydrates. Shoku no Kugaku, 135: 815, 1989

(54) Koyama H, Ogawa M, and Suzuki S: Relationship between total cholesterol and high-density lipoprotein cholesterol and the effects of physical exercise, alcohol consumption, cigarette smoking and body mass index. J Nutr Sci Vitaminol, 36 : 377-385, 1990

(55) Yamasaki R, Miyoshi T, Imaki M, and Nakamura $T$ : Evaluation of the effects of various factors on the serum triglyceride level in young adults. Tokushima $\mathrm{J}$ Exp Med, 41: 17-30, 1994

(56) Sasaki J: Control of serum lipids and prevention of atherosclerosis by exercise. Rinsho Seijinbyo, 25: 1260-1263, 1995

(57) Nakagawa $\mathrm{N}$ and Hamamoto $\mathrm{H}$ : Effects of regular exercise on coronary risk factors. Sinryo to Shinyaku, 32 : 535-539, 1995

(58) Sakuta H, Takao K, Suzuki T, and Nakagawa K: Physical activity and health of members of the Japan Self-Defense Force. Relations of lack of exercise and blood pressure, liver function, and serum lipids. Natl Defense Med J, 43: 269-176, 1996

(59) Inoue S, lida N, Waku Y, Bessho Y, Dote Y, Nishiura K, and Kono K : Life-style and periodic health screening. Bull Osaka Med Coll, 56 : 8-14, 1997

(60) Hata K, Hata T, Miyazaki K, Kunishi H, and Masuda J : Effect of regular aerobic exercise on cerebrovascular tone in young women. J Ultrasound Med, 17 : 133-136, 1998

(61) Taguchi K, Hirose H, Shimada K, Kimura N, Genyo M, Morimasa A, Waiuchi $\mathrm{H}$, Minamisato $\mathrm{S}$, and Saito I: Relationship between the body fat ratio at periodical examination and life-style in school teachers. National Collegiate Association for the Study of Health Management, 35 : 33-40, 1998

\section{Exercise Therapy and Serum Lipids}

(62) Higuchi M, Hashimoto I, Yamakawa K, Tsuji E, Nishimuta $\mathrm{M}$, and Suzuki S: Effect of exercise training on plasma high-density lipoprotein cholesterol level at constant weight. Clin Physiol, 4 : 125-133, 1984

(63) Morino M, Saito Y, Kusuhara R, Kagawa Y, Ishikawa S, Toyokawa $\mathrm{H}$, and Aoki $\mathrm{J}$ : Changes in the serum lipid levels and body composition due to weight loss in obese individuals caused by a low-energy diet based on a modified meal-serving method and exercise. Bull Kagawa Nut Coll, 18: 69-79, 1987

(64) Tanaka K, Nakadomo F, and Maeda K: Effects of jogging/running training on cardiorespiratory fitness, serum lipids, and body composition in healthy males. Ann Physiol Anthrop, $7:$ 31-37, 1988 
(65) Ohta T, Kawamura T, Hatano K, Yokoi M, Uozumi Z, Okamoto M, Mizuno Y, Iwatsuka T, and Hashimoto S : Effects of exercise on coronary risk factors in obese, middle-aged subjects. Jpn Circ J, 54: 1459-1464, 1990

(66) Hashimoto I: Lipid metabolism and exercise. Kidney Dialysis, 31: 33-40, 1991

(67) Higuchi T, Matsumoto K, Tanada S, Nakamura T, Imaki $M$, and Miyosi $T$ : Effects of daily physical activity on serum lipid levels. J Jpn Ass Rural Med, 42 : 66-71, 1993

(68) Kashihara $\mathrm{H}$, Kawakubo $\mathrm{K}$, Katagiri A, Yanagihori $\mathrm{A}$, Gunji A, Sakamoto $S$, and Koda $M$ : Changes in the body weight, serum lipid levels, and insulin level in obese middle-aged women by exercise and nutritional guidance. Clin Sports Med, 10: 1090-1094, 1993

(69) Motoyama M, Kakunan Y, Kinoshita T, Irie T, Sasaki J, Kiyonaga $A$, Tanaka $\mathrm{H}$, and Shindo $\mathrm{M}$ : Effects of longterm mild aerobic training and its discontinuation on the serum lipid and lipoprotein levels in morbid elderly individuals. Tairyoku Kagaku, 43: 434-442, 1994

(70) Ishibashi K, Maeda M, Nishimoto K, Shimada Y, Okauchi $Y$, Matsumoto $Y$, and Nagano $M$ : Effects of 10week voluntary training in daily living on the blood lipid levels in middle-aged subjects. Clin Sports Med, 11 : 77-80, 1994

(71) Hirano K, Nishiyama $Y$, Yoshida N, Noda T, Toyomasu $\mathrm{K}$, Koga $\mathrm{Y}$, and Tojima $\mathrm{H}$ : Effects of a program to support efforts to improve the life-style in patients with adult diseases having coronary risk factors. Shinryo to Shinyaku, 31: 306-310, 1994

(72) Kawakubo K: Chronic diseases and Sports. Special issue of Karada no Kagaku, "New Knowledge of Sports Therapy" : 133-137, 1995

(73) Higashi Y, Sasaki S, Sasaki N, Nakagawa K, Ueda T, Yoshimizu A, Kurisu S, Matsuura H, Kajiyama G, and Oshima $T$ : Daily aerobic exercise improves reactive hyperemia in patients with essential hypertension. Hypertension, 33 (Part II) : 591-597, 1999

(74) Dawber TR: Physical activity and cardiovascular disease. In: The Framingham Study-The Epidemiology of Atherosclerotic Disease-. pp 157-171, Harvard Univ Press, Cambridge, 1980

(75) Paffenbarger RS Jr, Hyde RT, Wing AL, and Hsieh CC: Physical activity, all-cause mortality, and longevity of college alumni. N Eng J Med, 314: 605-613, 1986

(76) Blair SN, Kohol HW 3d, Paffenbarger RS Jr, Clark DG, Cooper $\mathrm{KH}$, and Gibbons LW: Physical fitness and all-cause mortality. A prospective study on healthy men and women. JAMA, 262 : 2395-2401, 1989

(77) Hashimoto I, et al. : Shin Esuka 21 Exercise Physiology. ed by the Study Group of Nutrition, Food Sciences, and Health Education, Dobun Shoin, Tokyo, 1987

(78) Sasaki J, Tanaka Y, Tanabe H, Saku K, Shindou M, and Arakawa $\mathrm{K}$ : Elevated levels of $\mathrm{HDL}_{2}$-cholesterol and apo A-1 in national class Japanese male marathon runners. Atherosclerosis, 70:175-177, 1988

(79) Sasaki J and Arakawa K: Exercise therapy and improvements in the life-style. Gendai Iryo, 23: 17271732, 1991

(80) American College of Sports Medicine: Guideline for Exercise Testing and Prescription. 4th Ed, Lea \& Febiger, Philadelphia, 1991
(81) Editorial Committee of the Tairyoku Kagaku, Japanese Society of Physical Fitness and Sports Medicine: Guidelines for Exercise Prescription, Nankodo, Tokyo, 1993

(82) Arakawa K: Hypertension and exercise. Clin Exp Hypertens, 15 : 1171-1179, 1993

(83) Despres JP and Lamarche B: Low-intensity endurance exercise training, plasma lipoproteins and the risk of coronary heart disease (review). J Intern Med 236 : 7-22, 1994

\section{Nutrition and Serum Lipids}

(84) Health Service Bureau, Ministry of Health and Welfare (ed.): Present Status of Nutrition of the Japanese: Results of 1994 National Nutritional Survey. pp 29-64, Daiichi Shuppan, Tokyo, 1998

(85) Association for the Study of Information Concerning Health and Nutrition (ed.): The 6th Revision of the Nutritional Requirements of the Japanese: Standards for Dietary Intakes. pp 53-57, Daiichi Shuppan, Tokyo, 1999

(86) Okinaka S: Total serum cholesterol levels in normal subjects in Japan. Jpn Circ J, 29: 505-510, 1965

(87) Oshima K: A study of the serum cholesterol and triglyceride levels in healthy Japanese. J Jpn Atherosclerosis Soc, 1: 101-108, 1973

(88) Public Hygiene Bureau, Ministry of Health and Welfare (ed.) : Report of the 1980 Basic Survey of Cardiovascular Diseases. pp 164-166, Jpn Heart Foundation, Tokyo, 1983

(89) Public Hygiene Bureau, Ministry of Health and Welfare (ed.) : Report of the Fourth Basic Survey of Cardiovascular Diseases. pp 211-217, Foundation for Promotion of Research on Cardio-vascular Disorders, Suita, 1993

\section{Dietary Habit and Serum Lipids}

(90) Asano E: Epidemiology of hyperlipidemia. Keio Igaku, 47 : 359-374, 1970

(91) Ikuta K, Uchida A, Iwasaki J,and Ishige T: Blood profile of middle-aged and elderly people in agricultural and fishing villages in the coastal area of Chiba Prefecture. J Jpn Ass Rural Med, 33: 732-741, 1984

(92) Hirai A : An epidemiological study of the dietary intake of eicosapentanoic acid (EPA) and platelet function in Japanese. J Jpn Soc Int Med, 74: 13-20, 1985

(93) Hashimoto S, Toyoshima H, Okamoto K, Maeda K, Yagyu S, Goto K, Owaki J, and Kato T: Degrees of the effects of nutritional intakes on the regional differences in the serum lipid concentrations in elderly people. Jpn J Public Health, 35 : 493-500, 1988

(94) Ando T, Yanagibashi T, Wakisaka I, and Tomari J: Relationships of the serum lipid composition with the life-style and values of health parameters in residents of an agricultural village in Kagoshima Prefecture. Jpn J Public Health, 37 : 752-760, 1990

(95) Egusa G, Murakami F, Ito C, Matsumoto $Y$, Kado S, Okamura M, Mori $\mathrm{H}$, Yamane $\mathrm{K}$, Hara $\mathrm{H}$, and Yamakido $M$ : Westernized food habits and concentrations of serum lipids in the Japanese. Atherosclerosis, 100: 249-255, 1993

(96) Iso H, Folsom AR, Sato S, Wu KK, Shimamoto T, Koike $\mathrm{K}$, lida $\mathrm{M}$, and Komachi $\mathrm{Y}$ : Plasma fibrinogen and its correlates in Japanese and US population samples. 
Arterioscler Thoromb, 13: 783-790, 1993

( 97 ) Toshima H, Koga $\mathrm{Y}$, Menotti A, Keys A, Blackburn H, Jacobs DR, and Seccareccia $F$ : The seven countries study in Japan twenty-five-year experience in cardiovascular and all-causes deaths. Jpn Heart J, 36 : 179-189, 1995

(98) Okita M, Yoshida S, Yamamoto J, Suzuki K, Kaneyuki T, Kubota M, and Sasagawa T : $n-3$ and n-6 fatty acid intake and serum phospholipid fatty acid composit in middle-aged women living in rural and urban areas in Okayama Prefecture. J Nutr Sci Vitaminol (Tokyo), 41 : 313-323, 1995

(99) Mizushima S, Moriguchi EH, Ishikawa $P$, Hekman $P$, Nara Y, Miura G, Moriguchi Y, and Yamori Y: Fish intake and cardiovascular risk among middle-aged Japanese in Japan and Brazil. J Cardiovasc Risk, 4 : 191-199, 1997

(100) Tsubono $Y$ and Tsugane $S$ : Green tea intake in relation to serum lipid levels in middle-aged Japanese men and women. Ann Epidemiol, 7 : 280-287, 1997

(101) JAS Working Committee for Investigation of the Guideline: Japanese Atherosclerosis Society Guideline for Diagnosis and Management of Hyperlipidemias for Prevention of Atherosclerosis-I. Diagnostic criteria, management criteria and target values of treatment for hyperlipidemias in adults. J Jpn Atherosclerosis Soc, 25: 1-34, 1997

(102) Mensink RP and Katan MB : Effect of dietary fatty acids on serum lipids and lipoproteins: A meta-analyses of 27 trials. Atheroscler Thromb, 12: 911-919, 1992

(103) Conner WE and Conner SL: Lipid-lowering diets. In : Lipoproteins in Health and Disease. ed by Betteridge DJ, Illingworth DR, and Shepherd J, pp 1111-1131, Arnold, London, 1999

(104) Mattson FH and Grundy SM : Comparison of effects of dietary saturated, monounsaturated and polyunsaturated fatty acids on plasma lipids and lipoproteins in men. J Lipid Res, 26 : 194-202, 1985

(105) Nestel PJ : Diet and hyperlipidemia-Current questions and controversies. In : Human Plasma Lipoproteins, ed by Fruchard JC and Shepherd J, pp 309-333, Walter deGruyter, Berlin, 1989

(106) Tsimikas S and Reaven P: The role of dietary fatty acids in lipoprotein oxidation and atherosclerosis. Curr Opin Lipidol, 9 : 301-307, 1998

(107) Conner WE and Conner SL: Diet, atherosclerosis and fish oil. In: Advances in Internal Medicine, ed by Stollerman HS, Year Book 35 : pp 139-172, 1989

(108) Hornstra G: Dietary fats and arterial thrombosis. Haemostatis, 2 : 21-52, 1973

(109) Goodnight SH Jr, Harrio WS, Conner WE, and Illingworth DR: Polyunsaturated fatty acids, hyperlipidemia and thrombosis. Arteriosclerosis, 2: 87-113, 1982

(110) Conner WE and Conner SL: The dietary treatment of hyperlipidemia rationale, technique and efficacy. In: Lipid Disorders, Medical Clinics of North America, ed by Havel RJ, pp 485-518, WB Saunders, Philadelphia, 1982

(111) Jenkins $\mathrm{D}$, Wolever $\mathrm{T}$, Venketestriwer RAO, et al: Effect on blood lipids of very high intakes of dietary fiber in diets low saturated fat and cholesterol. N Engl J Med, 329 : 21-26, 1993

(112) Hirayama $Y$ : Eating fish and health: Mortality rates due to different causes according to the frequency of intake of seafood. Chugai lyaku, 45: 157-162, 1992

\section{Dietary Guidance and Dietary Therapy}

(113) Kato J, Kazumi B, Okutani T, Kasama T, Yoshino G, Yoshida M, and Baba S: Effects of loss of body weight on risk factors of atherosclerosis. J Jpn Diabetes Soc, 32: 319-323, 1989

(114) Murahata M, Tsuchiya H, Saka Y, Nakatsu C, Matsu$\operatorname{tani} S$, and Sato K: Dietary therapy for fatty liver. JJPEN, 11: 361-363, 1989

(115) Iso $H$, Konishi $M$, Koyama $M$, Tanigaki $M$, Baba $M$, Takemori T, Taketsuna K, Yamanaka Y, Itagaki Y, Shimano M, Fujitani Y, Nakamura M, Sato S, Terao A, lida $\mathrm{M}$, Shimamoto $\mathrm{T}$, and Komachi $\mathrm{Y}$ : Guidance of living for hypercholesterolemic individuals living in cities and its effects. Comparison between an intensive guidance group and ordinary guidance group. Jpn J Public Health, 38: 751-760, 1991

(116) Narikawa T: Therapeutic diet based primarily on the control of energy and lipid intakes. New Diet Therapy, 9: 7-16, 1993.

(117) Tanaka S, Yoshida $T$, and Kawakami $H$ : Effects of dietary intervention by STEP 1 DIET in female high school students with hypercholesterolemia. Jpn J School Health, 35 : 405-412, 1993

(118) Umemura U, Itoh I, Iso H, Koike K, Kamebayashi M, Sugiyama S, Kudo M, Sato S, lida M, Shimamoto T, and Komachi $Y$ : Dietary habit and serum lipid composition in female college students. Jpn J Public Health, 40 : 1139-1153, 1993

(119) Seki $M$ and Yamaguchi T : Effects of dietary guidance in hypercholesterolemic individuals at basic health examination at the health center. Jpn J Public Health, $40: 440-449,1993$

(120) Nakazawa A, Nishimura S, Azuma A, Ozasa K, Hayashi K, Watanabe Y, Aoike A, Kawai T, and Ikeda J : Effects of nutritional guidance for individuals with hypercholesterolemia during comprehensive health examination. Jpn J Nutr, 54 : 173-182, 1996

(121) Yamamoto $M$, Ohni M, Hata $Y$, Kitamoto $K$, Nagasawa $\mathrm{T}$, Nagasawa K, and Mori K : Effects of diet and cholesterol-lowering drug therapy for hypercholesterolemia in patients with hypertension under medication. Jpn J Geriatrics, 33: 79, 1996

(122) Yamashita K, lijima K, Watanabe $Y$, and Shirasawa A : Relationships between body mass index and lipids in elderly women with primary hyperlipidemia-A one-year follow-up study after introduction of dietary change. J Jpn Ass Rural Med 46 :755-759, 1997

(123) Konishi S, Konishi Y, Suzuki A, and Kusunoki T: A study of dietary guidance for weight control in housewives (part V): Changes in the contents of meals in subjects who showed improvements in the serum lipid profile. Bull Mukogawa Women's Coll (Natural Science), $45: 79-85,1997$

(124) Konno H, Ohira T, Kudo M, Sankai M, Tanigawa T, Iso $\mathrm{H}$, Shimamoto T, Umemura U, Koike K, Sato S, and lida $M$ : Effects of fish intake on the function, number, and metabolism of platelets in healthy Japanese. Jpn $\mathrm{J}$ Hygiene, 53 : 601-610, 1999

(125) Castelli WP: The epidemiology of blood lipids. In: Primary Hyperlipidemias, ed by Steiner $\mathrm{G}$ and Shafrir E, 
pp 119-142, McGraw-Hill , New York, 1991

(126) Nanbu K: Therapeutic diet based primarily on controlled energy and lipid intake: Necessity of nutritional examination. New Diet Therapy, 9: 1-6, 1993

(127) Taskinen MR and Nikkila EA : Effects of caloric restriction on lipid metabolism in man. Changes of tissue lipoprotein lipase activities and of serum lipoproteins. Atherosclerosis, 32 : 289-299, 1979

(128) Denke MA and Grundy SM: Individual responses to cholesterol-lowering diet in 50 men with moderate hypercholesterolemia. Arch Intern Med, 154: 317325, 1997

(129) Gould KL and Lipscomb K: Effects of coronary stenoses on coronary flow reverse and resistance. Am J Cardiol, 84 : 48-55, 1974

(130) Yutani C: Natural history of atherosclerotic lesions and its association with risk factors for cardiovascular disease. Annual Report of the Research on Cardiovascular Disease, pp 614-616, National Cardiovas- cular Center, Suita, 1997

(131) Bierman EL: Dietary treatment of hyperlipidemias. In: Primary Hyperlipoproteinemias. ed by Steiner G and Shafrir E, pp 303-319, McGraw-Hill, Now York, 1991

(132) Lipid Research Clinics Program: The Lipid Research Clinics Coronary Primary Prevention Trial results. I. Reduction in incidence of coronary heart disease. JAMA, 251: 351-364, 1984

(133) Lipid Research Clinics Program : The Lipid Research Clinics Coronay Primary Prevention Trial results. II. The relationship of reduction in incidence of coronary heart disease to cholesterol lowering. JAMA, 251: 365-374, 1984

(134) Reaven GM: Role of insulin resistance in human disease. Diabetes, 37 : 1595-1607, 1988

(135) Kaplan NM : The deadly quartet, upper body obesity, glucose intolerance, hypertriglyceridemia and hypertension. Arch Intern Med, 149: 1514-1520, 1989 